\title{
1 Systematic review reveals multiple sexually antagonistic 2 polymorphisms affecting human disease and complex
}

\section{3 traits}

4

5 Jon Alexander Harper ${ }^{1 *}$, Tim Janicke ${ }^{2,3}$ and Edward H. Morrow ${ }^{4}$

$6 *$ Corresponding author

$7 \quad{ }^{1}$ Evolution, Behaviour and Environment Group, School of Life Sciences, John Maynard Smith

8 Building, University of Sussex, Brighton, BN1 9QG, UK.

$9{ }^{2}$ Centre d'Écologie Fonctionnelle et Évolutive, UMR 5175, CNRS, Université de Montpellier, 10 École Pratique des Hautes Études, Montpellier, France.

$11{ }^{3}$ Applied Zoology, Technical University Dresden, Zellescher Weg 20b, 01062 Dresden,

12 Germany.

$13{ }^{4}$ Department of Environmental and Life Sciences, Karlstad University, 651 88, Karlstad,

14 Sweden.

15

Jon Alexander Harper ORCID: 0000-0002-1765-9990

17 Tim Janicke ORCID: $\underline{0000-0002-1453-6813}$

18 Edward H Morrow ORCID: 0000-0002-1853-7469

Short title: Systematic review of sexually antagonistic genes in human disease 
medRxiv preprint doi: https://doi.org/10.1101/2020.12.16.20248300; this version posted February 12, 2021. The copyright holder for this preprint (which was not certified by peer review) is the author/funder, who has granted medRxiv a license to display the preprint in It is made available under a CC-BY-NC 4.0 International license .

23 Abstract

24 An evolutionary model for sex differences in disease risk posits that alleles conferring higher 25 risk in one sex may be protective in the other. These sexually antagonistic (SA) alleles are 26 predicted to be maintained at frequencies higher than expected under purifying selection

27 against unconditionally deleterious alleles, but there are apparently no examples in humans.

28 Discipline-specific terminology, rather than a genuine lack of such alleles, could explain this 29 disparity. We undertook a two-stage review of evidence for SA polymorphisms in humans 30 using search terms from (i) evolutionary biology and (ii) biomedicine. While the first stage 31 returned no eligible studies, the second revealed 51 genes with sex-opposite effects, 22 32 increased disease risk or severity in one sex but protected the other. Those with net positive 33 effects occurred at higher frequencies. None were referred to as SA. Our review reveals 34 significant communication barriers to fields as a result of discipline-specific terminology. 148 words 
medRxiv preprint doi: https://doi.org/10.1101/2020.12.16.20248300; this version posted February 12,2021 . The copyright holder for this preprint (which was not certified by peer review) is the author/funder, who has granted medRxiv a license to display the preprint in It is made available under a CC-BY-NC 4.0 International license .

\section{Introduction}

In species with separate sexes an evolutionary conflict at the level of individual genetic loci can occur, where alleles that are favoured by selection in one sex are selected against in the other (i.e intralocus sexual conflict, Parker, 1979). This sexually antagonistic (SA) form of selection is thought to be driven by differences in how the two sexes maximize their fitness and concomitant unequal variances in reproductive success. Research into SA selection has expanded recently with the recognition that it feeds into several important evolutionary processes. It is primarily thought to drive the evolution of sexual dimorphism and trait diversification (Lande, 1980; Pennell et al., 2016; Rice, 1984), including sex-biased gene expression (Ellegren and Parsch, 2007). As a potential driver of balancing selection, it has also been implicated in the maintenance of genetic variation (Connallon and Clark, 2013; Grieshop and Arnqvist, 2018) that would otherwise be eroded by directional selection. Most recently, it has been suggested that genetic variation at SA loci could contribute to the occurrence of a number of common human diseases (Morrow, 2015; Morrow and Connallon, 2013), which also show considerable variation between the sexes in terms of their prevalence, severity and age of onset (Ober et al., 2008; Rigby and Kulathinal, 2015).

Despite the interest in sexual antagonism as an evolutionary force, determining the identity of SA loci remains a major challenge (Ruzicka et al., 2020). An early empirical milestone in the field of sexual conflict was achieved by quantitative genetic studies demonstrating that genomes in a laboratory adapted population of Drosophila melanogaster harbour significant amounts of SA standing genetic variation (Chippindale et al., 2001; Rice, 1992). A number of other systems have shown similar results, albeit using different methods, including invertebrates and vertebrates from both lab and wild populations (Bonduriansky and Chenoweth, 2009; Foerster et al., 2007; Mills et al., 2011). With the advent of advanced genomic tools, two model systems report specific examples of SA genetic loci: in Atlantic salmon (Salmo salar) the VGLL3 locus (Barson et al., 2015), and in D. melanogaster the DDTR locus (Rostant et al., 2015), the Ala-278-Thr polymorphism in the mitochondrial genome (Camus et al., 2015), and multiple candidate loci from a recent genome-wide association study (Ruzicka et al., 2019).

Although humans have also been shown to experience SA selection for some quantitative traits (Garver-Apgar et al., 2011; Stearns et al., 2012; Stulp et al., 2012), and there 
medRxiv preprint doi: https://doi.org/10.1101/2020.12.16.20248300; this version posted February 12, 2021. The copyright holder for this preprint (which was not certified by peer review) is the author/funder, who has granted medRxiv a license to display the preprint in

perpetuity.
It is made available under a CC-BY-NC 4.0 International license.

are numerous reports of genetic loci with sex-specific effects (i.e. effects that differ in magnitude between the sexes) on multiple complex traits or disease phenotypes (Gilks et al., 2014; Winkler et al., 2015), there are apparently no clear examples of SA loci in humans, which is inconsistent with theoretical expectations (Connallon and Clark, 2014). One potential explanation is that sexual antagonism is a weak selective force in humans, with sexual dimorphism being rather limited (Dixson, 2009; Short, 1979). This may indicate that concordant selection pressures between the sexes have dominated our evolutionary history. But the recent quantitative genetic studies challenge this view (Stearns et al., 2012; Stulp et al., 2012), and indeed theory predicts there is an inevitability to SA loci occurring in organisms with separate sexes (Connallon and Clark, 2014; Parker et al., 1972). Thus, there is a clear disparity between, on the one hand, theoretical expectations and quantitative genetic evidence that SA selection does occur in humans, and on the other hand, a complete lack of specific examples of SA loci. All this in the context of decades of research into how individual genetic variants influence disease profiles.

An alternative explanation for the absence of documented SA loci in humans is that since biomedical science does not use the same terminology for SA effects that evolutionary biology uses, there may in fact be examples that have been misclassified and therefore remain hidden in the literature. For example, genetic loci with sex-specific effects are frequently referred to as sex-dependent effects in the biomedical literature. Other terms are also used for related concepts, including sex-different effects. Furthermore, sex-opposite effects (i.e. a positive effect in one sex and a negative in the other) could be SA effects if the phenotype in question is deleterious, as disease phenotypes often are, since they can influence an individual's survival or reproductive fitness. The biomedical literature also frequently uses the terms sex and gender interchangeably, with males and females more often than not referred to as men and women, or boys and girls (Khramtsova et al., 2019). There is therefore ample scope for discipline-specific terms to be used for describing the same concept, which may hinder communication between disciplines and obscure examples of SA loci. Moreover, although there has been some progress in introducing concepts from evolutionary biology into the field of medicine (Nesse and Williams, 1994), those inroads have been relatively recent. It is therefore likely that the concepts of (intralocus) sexual conflict and sexual antagonism are not generally well known within biomedical science, and variants that may have SA effects on disease risk may not be referred to as such. A secondary related hypothesis 
medRxiv preprint doi: https://doi.org/10.1101/2020.12.16.20248300; this version posted February 12,2021 . The copyright holder for this preprint (which was not certified by peer review) is the author/funder, who has granted medRxiv a license to display the preprint in It is made available under a CC-BY-NC 4.0 International license .

100 is that SA effects, when discovered, are discounted as errors as they do not match 101 expectations that sex-differences in phenotype or genetic architecture are not important 102 (Clayton and Collins, 2014). As a result, that may also lead them to be misclassified or simply go unreported, leading to a general publication bias.

For these reasons, we propose that a systematic review of the biomedical literature to identify SA loci in humans requires a specific and targeted set of search terms that would not normally be used within the field of evolutionary biology. We test this assumption by dividing our systematic review into two stages. In the first stage, we search for papers identifying specific genetic loci using terms directly relating to the concept of sexual antagonism and others utilized in evolutionary biology. We supplement this search with a second stage, where we develop a set of terms that we hypothesize may capture the same concept as sexual antagonism within the biomedical literature, although not explicitly stated as such, as well as additional terminology relating to possible alternatives for describing the two sexes. From our searches we also extracted data on sex-specific effect sizes and allele frequencies. We were then able to explore how effect sizes varied for the same alleles between the sexes, and test the prediction that SA alleles experiencing net positive selection between the sexes may achieve higher equilibrium frequencies than alleles that experience more symmetric or net negative patterns of selection (Morrow and Connallon, 2013). Our systematic review aims to advance our understanding of SA genes in humans, which show considerable and largely unexplained diversity in sexual dimorphism for disease phenotypes (Ober et al., 2006; Rigby and Kulathinal, 2015), but we also highlight how and why interdisciplinary research (in this case between biology and medicine) can sometimes fail, impeding scientific advances over significant periods of time.

124 For this systematic review we followed PRISMA guidance where possible (Moher et al., 2009). 125 PubMed (https://pubmed.ncbi.nlm.nih.gov/) was searched for articles on $2^{\text {nd }}$ December 2020 with no time limit. The searches were carried out in two Stages, with the organism filter set to human in both stages. In Stage 1, eligible studies were required to report specific genetic variants or haplotypes that were referred to as sexually antagonistic or were an example of intralocus sexual conflict. To achieve this, we conducted a Boolean search for articles that 
medRxiv preprint doi: https://doi.org/10.1101/2020.12.16.20248300; this version posted February 12,2021 . The copyright holder for this preprint (which was not certified by peer review) is the author/funder, who has granted medRxiv a license to display the preprint in It is made available under a CC-BY-NC 4.0 International license.

131 AND "locus" OR "loci", "gene" OR "snp" OR "polymorphism" OR "variant" OR "allele" in their 132 abstract or title. The Stage 1 search returned 34 articles in total (full search term in the 133 supplementary material; search output is accessible 134 https://pubmed.ncbi.nlm.nih.gov/collections/60255050/?sort=pubdate).

135 In Stage 2, studies were required to report specific genetic variants or haplotypes in humans with opposite effects in the two sexes on either complex traits, the outcome of a medical intervention, or disease risk/severity. We define complex traits as likely with a polygenic genetic architecture but are not directly related to a disease phenotype. In this second stage search terms were specifically designed to include papers from the biomedical literature that may have been missed in the first stage because they do not report their findings with terms normally found within the evolutionary biology literature. Again, we conducted a Boolean search for articles that used terms in their title or abstract to describe an opposite or different effect in the two sexes ("sex dependent", "sex different", "genderdependent", "sex AND opposite", or "gender AND opposite"), or that capture this concept with alternative words for sex (("male AND female AND opposite" OR "men AND women AND opposite" OR "boys AND girls AND opposite") AND ("locus" OR "loci" OR "gene" OR "snp" OR "polymorphism" OR "variant" OR "allele")). Full details of the search terms used and the numbers of articles returned are provided in the supplementary material. The Stage 2 search returned 881 papers (Figure 1) (full search term in the supplementary material; search output is accessible at https://pubmed.ncbi.nIm.nih.gov/collections/60254985/?sort=pubdate). 2 by $\mathrm{JH}$, and any papers that had the possibility of reporting an opposite effect of a specific genetic locus on a complex trait, medical intervention or on disease risk/severity were considered for further screening. From Stage 1, no articles passed the screening. From Stage 2 , this screening produced a shortlist of 70 candidate papers

156 (https://pubmed.ncbi.nlm.nih.gov/collections/57906298/?sort=pubdate) Both JH and EM then reviewed all the full texts of these candidate papers in detail. Papers were included in the final list if they described a sex-opposite or SA effect linked to a specific genetic locus or loci, and reported the effect to be statistically significant (at a P-value cut-off of $<0.05$ ). One additional paper was considered from an outside source. 
medRxiv preprint doi: https://doi.org/10.1101/2020.12.16.20248300; this version posted February 12,2021 . The copyright holder for this preprint (which was not certified by peer review) is the author/funder, who has granted medRxiv a license to display the preprint in perpetuity.

It is made available under a CC-BY-NC 4.0 International license
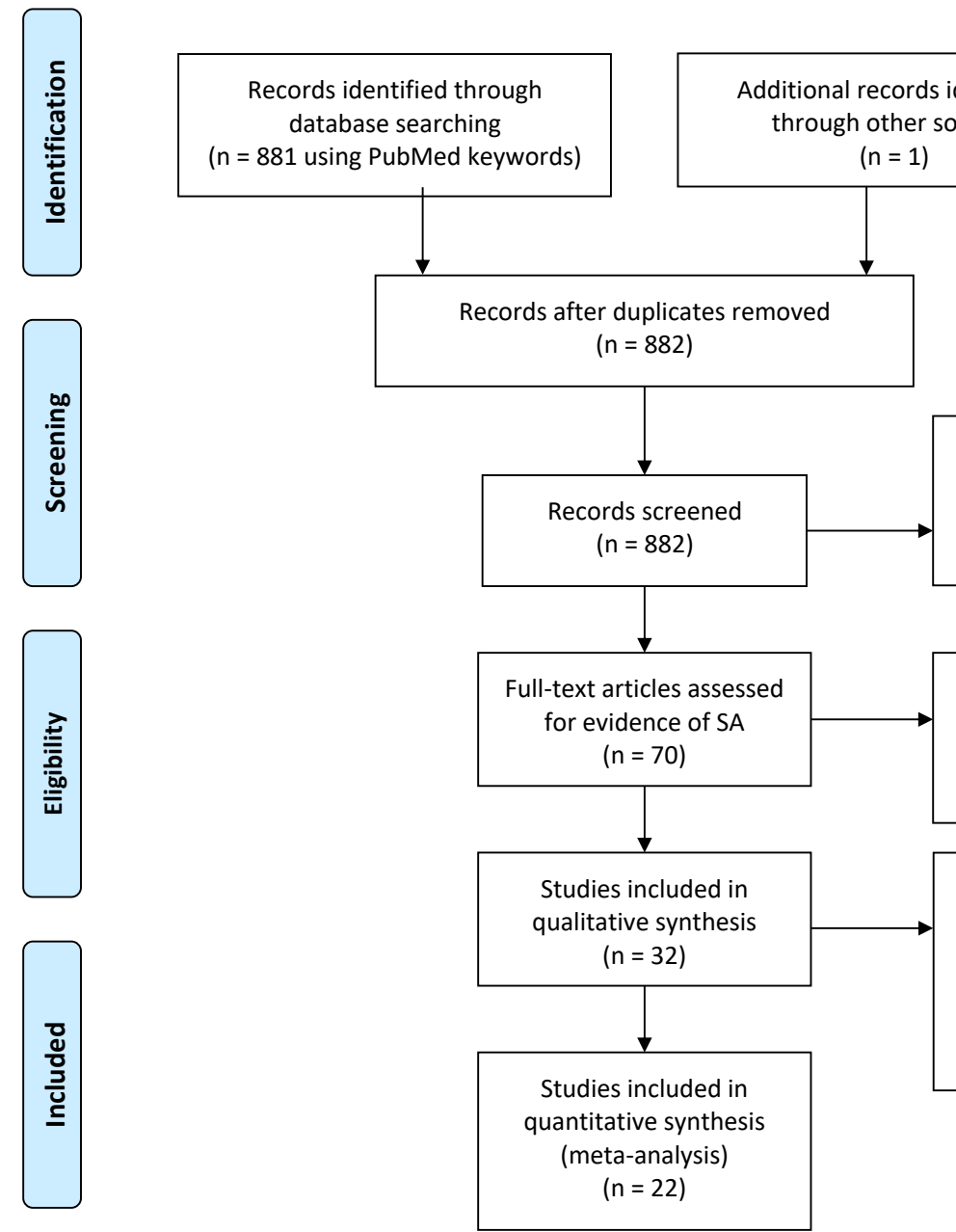

Records excluded (not in humans, did not describe a SA effect $(n=812)$

Figure 1. PRISMA flow diagram for systematic review of sexually antagonistic loci in humans. 
medRxiv preprint doi: https://doi.org/10.1101/2020.12.16.20248300; this version posted February 12,2021 . The copyright holder for this preprint (which was not certified by peer review) is the author/funder, who has granted medRxiv a license to display the preprint in

perpetuity.
It is made available under a CC-BY-NC 4.0 International license.

We converted all reported sex-specific effects into a standard effect size (Cohen's $d$ ) quantifying the magnitude of how a given variant affects the studied trait expressed in the given sex. Specifically, Cohen's $d$ was computed based on the reported descriptive statistics $(N$, mean, standard error) or by conversion from other effect sizes (Odds ratio) and test statistics ( $F$-values, $t$-values) using formulas reported elsewhere (Borenstein, 2009; Gurevitch et al., 2013, pp. 195-206; Lajeunesse, 2013). We sought information directly from the authors where these metrics were not possible to extract from the papers themselves (12 authors contacted, 5 responded, 3 responded with data, all later excluded as they did not fulfil the criteria for eligibility). We also recorded the gene name, locus (with accession/rs number where possible), trait affected and the frequency of the focal allele having the effect, hereafter referred to as effect allele frequency. Identification for the variants were taken from the studies where possible, but others necessitated searching the National Centre for Biotechnology Information (NCBI) to find the Reference SNP cluster ID for the variants described. Where effect allele frequencies were not reported, we used genotype frequencies to calculate effect allele frequency. Not all studies reported allele or genotype frequencies and so we attempted to supplement these data with allele frequencies from the 1000 genomes database (Auton et al., 2015), since these show a strong correlation with effect allele frequencies reported in the studies reviewed (Pearson correlation: $N=25 r=0.94, P>0.001$; Figure S1). However, using this approach we were only able to supplement our allele frequency data for one additional locus (rs7341475 in the RELN gene; Table 1).

If $b_{\mathrm{f}}$ and $b_{\mathrm{m}}$ represent the estimated effect of the focal allele in females and males respectively, then positive values of $b_{\mathrm{f}}$ or $b_{\mathrm{m}}$ imply that the allele is positively associated with disease expression, whereas negative values imply that the allele is negatively associated with disease expression. SA alleles are therefore defined as those with opposite effects between the sexes (i.e. $b_{\mathrm{f}}<0<b_{\mathrm{m}}$ or $b_{\mathrm{m}}<0<b_{\mathrm{f}}$ ). An evolutionary model of evolution at SA loci predicts that as the magnitude of the positive effect that an SA allele has outweighs the negative effect, the higher the frequency that allele can achieve (Morrow and Connallon, 2013). We therefore expect a negative relationship between the ratio of positive to negative effect sizes (hereafter referred to as the effect size ratio) and observed allele frequency. To investigate this, we calculated the effect size ratio by dividing the positive standardized effect size by the negative standardized effect size; when $b_{\mathrm{f}}<0<b_{\mathrm{m}}$ effect size ratio was calculated as $b_{\mathrm{m}} / b_{\mathrm{f}}$, and when $b_{\mathrm{m}}<0<b_{\mathrm{f}}$ effect size ratio was calculated as $b_{\mathrm{f}} / b_{\mathrm{m}}$. 
197 Table 1. Genetic loci in humans showing sexually antagonistic effects on trait expression. EAF, effect allele frequency $(*$ indicates allele 198 frequency derived from 100 genomes database); M, male; F, female. Background colours denote instances where genes and/or variants 199 appear more than once in the list.

\begin{tabular}{|c|c|c|c|c|c|c|c|c|}
\hline Trait & Gene & \begin{tabular}{|lll} 
Locus \\
\end{tabular} & EAF & M Effect & M Effect SE & F Effect & F Effect SE & Reference \\
\hline \multicolumn{9}{|l|}{ Complex traits } \\
\hline Concentration performance score & FADS1/2 & rs1535 & 0.672 & 0.2275 & 0.1065 & -0.2394 & 0.1116 & (Lauritzen et al., 2017) \\
\hline Reading speed, number of sentences & FADS1/2 & 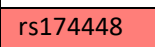 & 0.642 & 0.5511 & 0.1069 & -0.6074 & 0.1129 & $\begin{array}{l}\text { (Lauritzen et al., 2017) } \\
\end{array}$ \\
\hline Reading speed, number of sentences & ELOVL5 & rs2397142 & 0.695 & -0.1963 & 0.1042 & 0.2364 & 0.1095 & $\begin{array}{l}\text { (Lauritzen et al., 2017) } \\
\end{array}$ \\
\hline Reading speed, correct sentences & FADS1/2 & 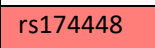 & 0.642 & 0.6599 & 0.1077 & -0.3451 & 0.1112 & $\begin{array}{l}\text { (Lauritzen et al., 2017) } \\
\end{array}$ \\
\hline Speed-dating success & OPRM1 & \begin{tabular}{|l|} 
rs1799971 \\
\end{tabular} & 0.922 & 0.4697 & 0.2275 & -0.53 & 0.2856 & (Wu et al., 2016) \\
\hline Speed-dating success & HTR2A & rs6311 & 0.418 & -0.4826 & 0.1982 & 0.4702 & 0.1964 & (Wu et al., 2016) \\
\hline Waist-hip-ratio (BMI adjusted) & SIM1 & rs17185536 & 0.76 & -0.0166 & 0.008 & 0.0264 & 0.0067 & (Winkler et al., 2015) \\
\hline Waist-hip-ratio (BMI adjusted) & NMU & \begin{tabular}{|l|}
$r s 3805389$ \\
\end{tabular} & 0.28 & -0.0139 & 0.0067 & 0.0261 & 0.006 & (Winkler et al., 2015) \\
\hline Waist-hip-ratio (BMI adjusted) & GNPNAT1 & \begin{tabular}{|l|} 
rs48988764 \\
\end{tabular} & 0.53 & 0.0208 & 0.0066 & -0.0165 & 0.0059 & (Winkler et al., 2015) \\
\hline Waist-hip-ratio (BMI adjusted) & SGCZ & rs17470444 & 0.71 & 0.0345 & 0.0081 & -0.0149 & 0.0068 & (Winkler et al., 2015) \\
\hline Waist-hip-ratio (BMI adjusted) & IQGAP2 & rs2069664 & 0.53 & 0.0244 & 0.0078 & -0.0183 & 0.0067 & (Winkler et al., 2015) \\
\hline Waist-hip-ratio (BMI adjusted) & SLC2A3 & rs741361 & 0.6 & 0.0272 & 0.0079 & -0.0196 & 0.0067 & (Winkler et al., 2015) \\
\hline Waist-hip-ratio (BMI adjusted) & IRS1 & rs2673140 & 0.38 & 0.022 & 0.0066 & -0.0209 & 0.0059 & (Winkler et al., 2015) \\
\hline Waist-hip-ratio (BMI adjusted) & TTN & rs2042995 & 0.23 & 0.0198 & 0.0066 & -0.022 & 0.0078 & (Winkler et al., 2015) \\
\hline Waist-hip-ratio (BMI adjusted) & RXRA & rs10881574 & 0.07 & 0.0268 & 0.008 & -0.0191 & 0.0067 & (Winkler et al., 2015) \\
\hline Waist-hip-ratio (BMI adjusted) & PTPRD & rs7042428 & 0.98 & 0.0244 & 0.0071 & -0.0166 & 0.0063 & (Winkler et al., 2015) \\
\hline Waist-hip-ratio (BMI adjusted) & CECR2 & rs17809093 & 0.04 & 0.0294 & 0.0091 & -0.024 & 0.0077 & (Winkler et al., 2015) \\
\hline $\begin{array}{l}\text { Reaction time (RT) in the Stroop task, congruent } \\
\text { condition }\end{array}$ & CHRNA5 & \begin{tabular}{|r|r|}
$r s 3841324$ \\
\end{tabular} & 0.406 & -1.5421 & 0.3857 & 0.9945 & 0.2517 & (Schneider et al., 2015) \\
\hline $\begin{array}{l}\text { Reaction time (RT) in the Stroop task, incongruent } \\
\text { condition }\end{array}$ & CHRNA5 & rs3841324 & 0.406 & -1.6215 & 0.389 & 1.0215 & 0.2521 & (Schneider et al., 2015) \\
\hline Reaction time (RT) in the Negative priming task & CHRNA5 & rs3841324 & 0.406 & -1.675 & 0.3912 & 0.6299 & 0.247 & (Schneider et al., 2015) \\
\hline
\end{tabular}




\begin{tabular}{|c|c|c|c|c|c|c|c|c|}
\hline Borderline personality traits after maltreatment & OXTR & rs53576 & 0.738 & -0.3429 & 0.0881 & 0.2066 & 0.0857 & (Cicchetti et al., 2014) \\
\hline Borderline personality traits after maltreatment & FKBP5 & CATT haplotype & - & 0.2041 & 0.0877 & -0.195 & 0.0857 & (Cicchetti et al., 2014) \\
\hline fluid intelligence & C16orf62 (OXTR) & rs226849 & 0.46 & -0.3949 & 0.1869 & 0.494 & 0.1814 & (Kiy et al., 2013) \\
\hline face perception & C16orf62 (OXTR) & rs226849 & 0.46 & -0.5819 & 0.1909 & 0.3498 & 0.1788 & (Kiy et al., 2013) \\
\hline face memory & C16orf62 (OXTR) & rs226849 & 0.46 & -0.3679 & 0.1864 & 0.3562 & 0.1789 & (Kiy et al., 2013) \\
\hline Hippocampal volume & SLC6A4 & rs25531 & 0.39 & - & & - & & (Price et al., 2013) \\
\hline Sociopathy (in alcoholics) & SLC6A4 & rs 25531 & 0.51 & - & & - & & (Herman et al., 2011) \\
\hline systolic blood pressure S_NIGHT & PON1 & rs3917542 & - & -0.1047 & 0.0637 & 0.1129 & 0.0645 & $\begin{array}{l}\text { (Padmanabhan et al., } \\
\text { 2010) }\end{array}$ \\
\hline systolic blood pressure S_NIGHT & PON3 & rs17884563 & - & -0.1482 & 0.0637 & 0.1061 & 0.0645 & $\begin{array}{l}\text { (Padmanabhan et al., } \\
\text { 2010) }\end{array}$ \\
\hline systolic blood pressure S_CLIN & EDNRB & rs1335803 & - & -0.1308 & 0.0637 & 0.1129 & 0.0645 & $\begin{array}{l}\text { (Padmanabhan et al., } \\
\text { 2010) }\end{array}$ \\
\hline diastolic blood pressure D_NIGHT & DRD1 & rs265974 & - & -0.1482 & 0.0637 & 0.1502 & 0.0646 & $\begin{array}{l}\text { (Padmanabhan et al., } \\
\text { 2010) }\end{array}$ \\
\hline diastolic blood pressure D_HOME & SLC4A2 & rs2303933 & - & -0.1482 & 0.0637 & 0.1325 & 0.0646 & $\begin{array}{l}\text { (Padmanabhan et al., } \\
\text { 2010) }\end{array}$ \\
\hline diastolic blood pressure D_CLIN & LPL & rs17410577 & - & -0.1047 & 0.0637 & 0.1775 & 0.0647 & $\begin{array}{l}\text { (Padmanabhan et al., } \\
\text { 2010) }\end{array}$ \\
\hline Psychological Stress & BDNF & rs6265 & 0.149 & - & & - & & (Shalev et al., 2009) \\
\hline BMI standard deviation score (children) & FAS & rs2228305 & 0.0312 & -0.552 & 0.2259 & 0.4427 & 0.2075 & (Korner et al., 2007) \\
\hline Pain sensitivity & OPRM1 & rs1799971 & 0.8817 & - & & - & & (Fillingim et al., 2005) \\
\hline Central DBP & REN & rs6693954 & 0.22 & -0.4444 & 0.2132 & 1.1052 & 0.3923 & (Ljungberg et al., 2014) \\
\hline \multicolumn{9}{|l|}{ Disease risk/severity } \\
\hline Graves opthalmopathy in GD & PRR3 & rs2074503 & 0.3586 & 0.4397 & 0.1682 & -0.2185 & 0.0851 & (Liu et al., 2014) \\
\hline Colorectal cancer & LTA & rs1041981 & 0.32 & -0.0722 & 0.0368 & 0.1027 & 0.0453 & (Sainz et al., 2012) \\
\hline Arterial blood pressure & PPAR & rs1801282 & 0.1213 & - & & - & & (Franck et al., 2012) \\
\hline Schizophrenia risk & RELN & rs7341475 & $0.851^{*}$ & 1.2396 & 0.2819 & -0.762 & 0.3662 & $\begin{array}{l}\text { (Ovadia and Shifman, } \\
\text { 2011) }\end{array}$ \\
\hline Colon cancer survival & ESR2 & (CA)n repeats & - & 0.2272 & 0.0962 & -0.2046 & 0.1205 & (Press et al., 2011) \\
\hline Schizophrenia risk & DAO & rs2070586 & 0.2729 & 0.1982 & 0.0888 & -0.2537 & 0.0908 & (Kim et al., 2010) \\
\hline
\end{tabular}




\begin{tabular}{|c|c|c|c|c|c|c|c|c|}
\hline T2DM, fasting glucose & SCARB1 & rs9919713 & 0.04 & 0.1865 & 0.0853 & -0.2515 & 0.0697 & (McCarthy et al., 2009) \\
\hline Depression & SLC6A4 & rs25531 & 0.4586 & 0.5404 & 0.2277 & -0.3996 & 0.1859 & (Sjoberg et al., 2006) \\
\hline Infertility in cystic fibrosis & CFTR & rs213950 & 0.417931 & - & & - & & (Morea et al., 2005) \\
\hline Bone mineral density & APOE & rs429358 & 0.0798 & - & & - & & (Wong et al., 2005) \\
\hline Narcolepsy severity & COMT & Long allele & 0.4588 & 1.3596 & 0.3878 & -2.2152 & 0.4871 & (Dauvilliers et al., 2001) \\
\hline Nonsyndromic cleft lip & IMPK & rs11142081 & 0.863 & 1.2156 & 0.0937 & -1.1161 & 0.0783 & (Carlson et al., 2018) \\
\hline Nonsyndromic cleft lip & IMPK & rs72804706 & 0.898 & -0.816 & 0.0906 & 2.0665 & 0.0908 & (Carlson et al., 2018) \\
\hline Nonsyndromic cleft lip & IMPK & rs77590619 & 0.744 & -0.8577 & 0.0904 & 1.2291 & 0.0804 & (Carlson et al., 2018) \\
\hline Allergy & ACP1 & $\mathrm{A}^{*}$ allele (CG haplotype) & - & - & & - & & (Gloria-Bottini et al., 2007) \\
\hline Hepatitis C susceptability & IL-12B & rs3212227 & 0.3463 & - & & - & & (Youssef et al., 2013) \\
\hline RSV severity & IL-9 & rs2069885 & 0.15 & 0.1888 & 0.0933 & -0.2794 & 0.0957 & (Schuurhof et al., 2010) \\
\hline CV risk marker (plasma fatty acid composition) & FABP2 & rs1799883 & 0.287 & - & & - & & (Gastaldi et al., 2007) \\
\hline Bone mineral density & NR3C1 & GCAG haplotype & - & 0.6854 & 0.3676 & -0.9029 & 0.4311 & (Peng et al., 2008) \\
\hline Anxiety & NGF & rs6330 & 0.451 & 0.4562 & 0.18 & -0.4674 & 0.1817 & (Lang et al., 2008) \\
\hline Melanoma risk & RNASEL, miR-146a & AG/AA and C haplotype & - & 0.4525 & 0.1564 & -0.3553 & 0.174 & (Sangalli et al., 2017) \\
\hline
\end{tabular}


medRxiv preprint doi: https://doi.org/10.1101/2020.12.16.20248300; this version posted February 12,2021 . The copyright holder for this preprint (which was not certified by peer review) is the author/funder, who has granted medRxiv a license to display the preprint in It is made available under a CC-BY-NC 4.0 International license .

Thus, SA alleles with a greater beneficial effect will have a smaller, more negative effect size ratio (<-1), while SA alleles that have a greater deleterious effect will have a larger effect size ratio (>-1), up to a maximum value of 0 (positive values occur when the effect is positive or negative in both sexes, but the allele would then no longer be defined as a SA allele).

We modelled how effect allele frequency changes with effect size ratio using a generalized linear model (GLM), weighted by the inverse of the variance of the effect sizes such that data points with smaller variance have a higher weight, since smaller sample sizes were associated with larger and more variable effect sizes (Figure S2). We initially also included trait class and its interaction with effect size ratio as a fixed factor with two levels (complex trait and disease trait/severity), since alleles that influence complex traits in opposite directions are not necessarily under SA selection and so may not behave in the way predicted, whereas alleles influencing disease traits, unless very late acting, are more likely to show a closer relationship with marginal effects on fitness. As a response variable, effect allele frequency is limited between 0 and 1, so we looked at allele counts to allow allele frequency to vary freely. GLMs with binomial error distribution showed substantial overdispersion, so we used a quasibinomial function to address this issue (Payne et al., 2018). We used a Chi-squared test to infer significance of the two predictor variables and their interaction. The full model indicated that the interaction term and trait class have no significant effect, so that we report the fit of the reduced model which only includes effect size ratio. We also subsequently modelled the data for the two trait classes (complex traits and disease risk/severity) separately, again using a quasibinomial distribution function, to see if the result was replicated in these smaller subsets of the data. The raw data and $\mathrm{R}$ script is available for replicating the analyses and figures we present (Supplementary Material).

\section{Results}

The Stage 1 search found no articles that described genetic loci in humans with effects that were sexually antagonistic. In contrast, the Stage 2 search identified 32 articles that described variants with statistically significant sex-opposite or SA effects (Figure 1; https://pubmed.ncbi.nlm.nih.gov/collections/60278165/?sort=pubdate). From the studies examined, 51 SA variants were identified (Table 1), affecting 21 different complex traits (30 
medRxiv preprint doi: https://doi.org/10.1101/2020.12.16.20248300; this version posted February 12, 2021. The copyright holder for this preprint (which was not certified by peer review) is the author/funder, who has granted medRxiv a license to display the preprint in

perpetuity.
It is made available under a CC-BY-NC 4.0 International license.

233

234

235

236

237

238

239

240

241

242

243

244

245

246

247

248

249

250

251

252

253

254

255

256

257

258

259

260

261

262

263

no variants affecting medical intervention traits that passed the screening process. The majority of alleles had effect sizes of similar absolute values in the two sexes, with larger effects tending to show greater differences on absolute effect size (Figure S3).

We found 22 studies provided sufficient data to allow the relationship between effect size ratio and effect allele frequency to be explored by statistical modelling. Trait class and its interaction with effect size ratio were initially included in the model but neither were found to have a significant effect (GLM: trait class $\mathrm{dfs}=1,35$, deviance $=15.5 \times 10^{3}, P=0.965$; interaction $\mathrm{dfs}=1,34$, deviance $=1476, \mathrm{P}=0.989$ ) and were therefore excluded from the subsequent model in which effect size ratio was found to relate negatively to effect allele frequency, as predicted (GLM: estimate $\pm \mathrm{SE}=-1.10 \pm 0.50, \mathrm{dfs}=1,36$, deviance $=38.7 \times 10^{6}$, $P=0.024 ;$ Figure 2). For three loci there were data on effect sizes for more than one trait (Table 1), which introduced a degree of non-independence between these values in the dataset. However, resampling the data with effect sizes for only one trait for these three loci in turn and modelling these datasets in the same way (18 individual GLMs, $d f s=1,31$ ) did not change the results qualitatively (minimum, maximum: model estimate $=-1.0963,-1.0964$; deviance $=38.72 \times 10^{6}, 38.73 \times 10^{6} ; P=0.03618,0.03620$ ).

Although the interaction term between trait type and effect size ratio was not significant we wanted to investigate whether the negative relationship between effect size ratio and effect allele frequency across all loci was repeated when the data was divided according to trait class, since while opposite effects on disease risk/severity may show a direct relationship with SA fitness effects, complex traits may or may not be experiencing SA selection, even if effects are in opposite directions in the two sexes. However, although the trends were both again negative as predicted, the generalized linear models of these smaller datasets were only marginally significant (complex traits model estimate \pm SE $=-1.10 \pm 0.61$, $\mathrm{dfs}=1,24$, deviance $=38.7 \times 106, \mathrm{P}=0.065$; disease risk/severity model estimate $\pm \mathrm{SE}=-1.34$ $\pm 0.77, \mathrm{dfs}=1,10$, deviance $=5.14 \times 104, \mathrm{P}=0.053$; Figure S4). As for the full dataset, there was some lack of independence for the complex traits subset which contained loci with effect sizes for more than one trait. Again, resampling and modelling these datasets in the same way (18 individual glms, dfs 1, 22) did not change the results quantitatively (minimum, maximum: model estimate $=-1.0960,-1.0961 ;$ deviance $=38.669 \times 10^{6}, 38.675 \times 10^{6} ; P=$ $0.07774,0.07776)$. 
medRxiv preprint doi: https://doi.org/10.1101/2020.12.16.20248300; this version posted February 12, 2021. The copyright holder for this preprint (which was not certified by peer review) is the author/funder, who has granted medRxiv a license to display the preprint in It is made available under a CC-BY-NC 4.0 International license .

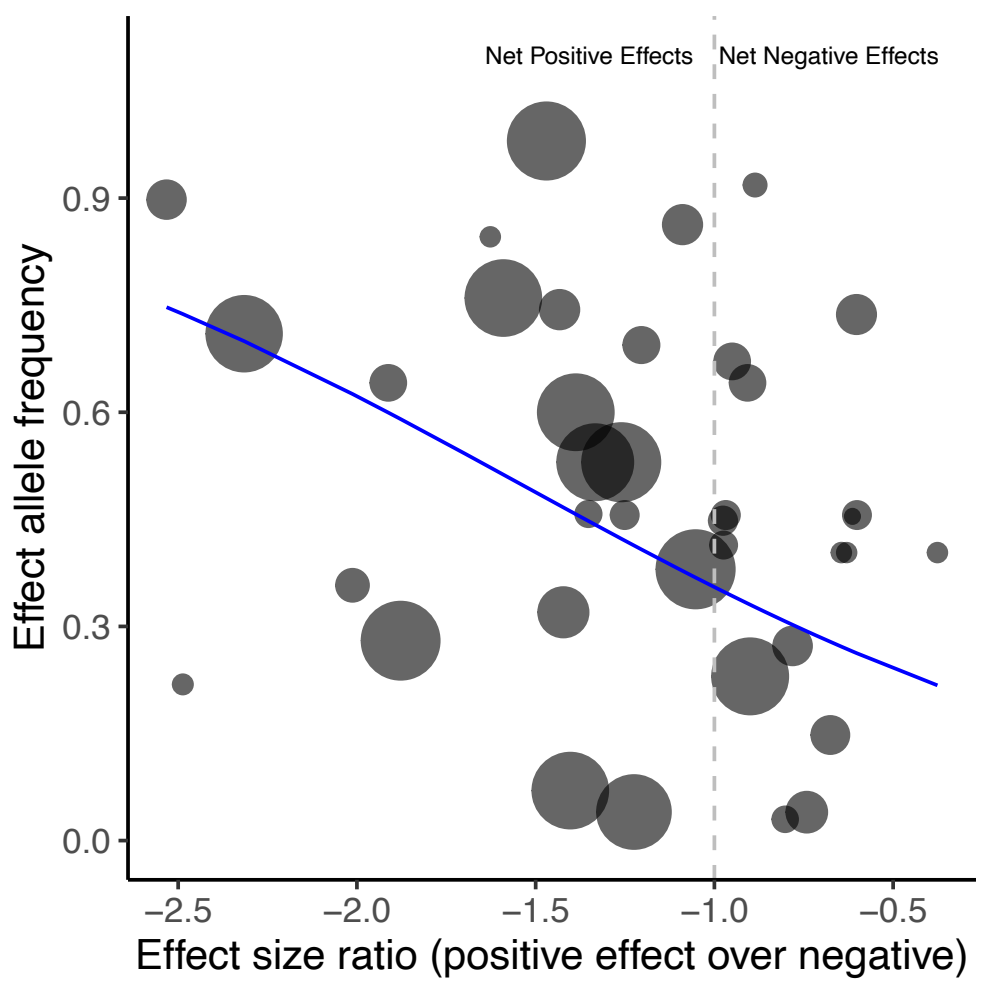

265 Figure 2. The relationship between effect allele frequency and effect size ratio. Point size varies according to the variance of effect size ratio - larger points have smaller variance and therefore a larger weighting in the model. The vertical dotted line represents the switch point between a net-negative effect of a particular locus (effect size ratio >-1) and a net positive effect (effect size ratio <-1). The blue line represents the predicted values derived from the generalized linear model fitted to the data (see Results). 
medRxiv preprint doi: https://doi.org/10.1101/2020.12.16.20248300; this version posted February 12, 2021. The copyright holder for this preprint (which was not certified by peer review) is the author/funder, who has granted medRxiv a license to display the preprint in It is made available under a CC-BY-NC 4.0 International license .

\section{Discussion}

The Stage 1 literature search of our systematic review focussed on finding reports of specific genetic loci in humans with evidence for SA effects using terminology normally associated with the evolutionary concepts of sexual conflict or sexual antagonism. The Stage 2 search sought equivalent evidence, but used search terms that we anticipated would be used by scientists outside the field of evolutionary biology, who may not use the same terminology. Although the Stage 1 search did not find any examples of SA loci occurring in humans, the Stage 2 search identified 51 genetic loci across 39 studies that had ostensibly SA effects, but were not described as such. Clearly then the Stage 1 review failed to identify multiple relevant reports going back some 20 years because the terminology used in those reports did not match the conceptual framework of the search. The Stage 2 search may also be a lower limit given searches of other larger databases may also harbour further examples (see below). Although not yet validated, these reports nonetheless represent a substantial body of evidence that humans, like other organisms with separate sexes (Bonduriansky and Chenoweth, 2009), inevitably experience SA selection for a wide range of complex traits (Connallon and Clark, 2014; Garver-Apgar et al., 2011; Stearns et al., 2012; Stulp et al., 2012), as well as for a range of diseases.

A key prediction from a population genetic model of SA genetic variation is that SA alleles are expected to achieve higher equilibrium frequencies, without necessarily going to fixation, as the relative magnitude of the positive effect in one sex outweighs the negative effect in the opposite sex i.e. an increasingly negative effect size ratio (Morrow and Connallon, 2013). We found clear support for this prediction, with a negative relationship between effect size ratio and allele frequency when examining all complex traits and diseases together (Fig 2), although this relationship was only marginally significant when complex or disease trait classes were modelled separately (Fig S3). These results lend support to the view that the loci identified are genuinely experiencing SA selection, and although it is difficult to discern how selection acts on trait size in males and females for complex traits we would not expect the frequencies of disease-causing alleles to be so high under a mutation-selection balance. We were not able to look at the evolutionary history or age of these alleles due to limited information ( $n=8$ ) (Albers and McVean, 2018), it would nonetheless be valuable to examine the population dynamics of these alleles over a broad timescale. 
medRxiv preprint doi: https://doi.org/10.1101/2020.12.16.20248300; this version posted February 12, 2021. The copyright holder for this preprint (which was not certified by peer review) is the author/funder, who has granted medRxiv a license to display the preprint in It is made available under a CC-BY-NC 4.0 International license .

The loci showed a very broad range of effect sizes, from small to very large, with a generally symmetrical inverse relationship between effect size in one sex and the other (Figure S2), which is generally expected, since our screening process necessarily excluded studies reporting effects in the same direction across the two sexes. Nonetheless, it is striking just how large some of the effects were, with very large negative effects in one sex simultaneously occurring with similarly large positive effects. Larger and more variable effect sizes are expected when sample sizes are small, a pattern we also found, which motivates further investigation of the traits and loci included in this review to elucidate more accurate estimates of real effect sizes.

The loci themselves fall within genes that influence a broad range of phenotypes, including morphological, physiological and behavioural complex traits, and a similarly diverse range of disease types, including various cancers, neurological disorders and immune system processes (see Table 1). For the most part, the diseases appear to be early-acting rather than late-onset, with the exception of perhaps bone mineral density. As such, it seems reasonable that an allele that increases disease risk or severity in these cases will indeed have a concomitant reduction in marginal fitness. Although a single large study identified several loci related to BMI adjusted waist-to-hip ratio, there is generally no overall bias towards one particular trait or disease class. The total number of loci is relatively small however, which may limit power to identify such biases if they exist. We also did not find any examples of SA loci on the X-chromosome, which may or may not be a hotspot of sexual antagonism (Fry, 2010; Rice, 1984; Ruzicka and Connallon, 2020). This was expected given that it is commonly not included in genome-wide analyses (Wise et al., 2013), although most of the papers we reviewed were candidate gene studies. Nonetheless, we anticipate further examples may be identified should data from the X-chromosome be included systematically in association studies.

We also found evidence that some traits are influenced by more than one genetic variant in sex-opposite or SA ways $(n=8)$, or that some specific variants have pleiotropic effects on more than one trait or disease in a sex-opposite or SA way ( $n=6$; see Table 1$)$. This complexity in the genetic architecture of traits or diseases may make conflict resolution particularly difficult, as a change in the allele at a single genetic locus experiencing SA selection may simultaneously influence multiple genes or phenotypes in both sexes in divergent ways (Fitzpatrick, 2004; Pennell and Morrow, 2013). Consequently, this may explain 
medRxiv preprint doi: https://doi.org/10.1101/2020.12.16.20248300; this version posted February 12, 2021. The copyright holder for this preprint (which was not certified by peer review) is the author/funder, who has granted medRxiv a license to display the preprint in

It is made available under a CC-BY-NC 4.0 International license.

334

335

336

337

338

339

340

341

342

343

344

345

346

347

348

349

350

351

352

353

354

355

356

357

358

359

360

361

362

363

364

365

the persistence of intralocus sexual conflict at these loci. It may be that some of the remaining loci also have as yet unidentified pleiotropic effects with other traits or there are as yet unidentified SA loci influencing those same traits or diseases. Of the 51 variants identified, 4 were confirmed to be haplotypes. Such variants, consisting of two or more SNPs in linkage disequilibrium having a joint effect, could also present a problem for conflict resolution, since the ability of selection to act on any individual locus independent of the others in the linkage block is reduced for linked loci. This issue may also extend to other single variants reported here if they also occur in linkage blocks.

Although we have identified multiple genetic loci with either sex-opposite or SA effects these are likely outnumbered by those with either sex-specific (same direction but different magnitude) or sex-limited effects. For instance, Winkler et al. (2015) report 44 loci with sex-specific or sex-limited effects but only 11 with sex-opposite effects. Several other genome-wide association studies report sex-specific effects in several human diseases (Khramtsova et al., 2019), and a recent (non-systematic) review identified 37 SNPs with sexdependent effects (Gilks et al., 2014). Detection of loci with SA versus sex-specific or sexlimited effects may differ systematically since we expect SA loci are more likely to persist at intermediate frequencies than loci with sex-specific effects (i.e. that differ between the sexes in magnitude but not sign). A larger systematic review that targeted variants with sex-specific or sex-dependent effects would therefore be a valuable contribution and enable us to more clearly understand how important SA alleles are relative to the broader context of genes with non-identical effects in the two sexes.

A key gap in our knowledge is whether the putative examples of sex-opposite or SA alleles presented here can be validated using independently derived datasets in the same or different sub-populations. For this, focussing on those variants associated with sexdifferential disease risk would naturally be the most fruitful for advancing our knowledge of sexual antagonism in human disease. We therefore encourage specialists for the particular disease groups presented in Table 1 to include in the future the potential for SA genetic effects to occur when designing studies and analysing data. It is also important for all studies to report results in sufficient detail so that effect sizes can be calculated (if not given) as well as allele frequency data. Unfortunately, 17 studies failed to do this, so could not be included in our review and subsequent test of the evolutionary model. More generally, our study reinforces the view that sex is an important factor in shaping genetic associations with human 
medRxiv preprint doi: https://doi.org/10.1101/2020.12.16.20248300; this version posted February 12, 2021. The copyright holder for this preprint (which was not certified by peer review) is the author/funder, who has granted medRxiv a license to display the preprint in It is made available under a CC-BY-NC 4.0 International license.

366

367

368

369

370

371

372

373

374

375

376

377

378

379

380

381

382

383

384

385

386

387

388

389

390

391

392

393

394

395

396

397

traits and disease, even in divergent and contradictory ways, and so should always be considered when investigators examine genetic associations with phenotypes (Lee, 2018; Ober et al., 2008).

There is a possibility that some bias exists in the PubMed database against papers from the field of evolutionary biology, and if we had used another database then both stages would have returned valid papers. We subsequently $\left(14^{\text {th }}\right.$ Dec 2020$)$ sought to investigate this possibility with additional searches of Scopus and Web of Science. Repeating the Stage 1 search initially returned 85 papers in Web of Science (Basic search of Topic, refined by "Human" within results) and 71 papers in Scopus (include keywords "Human", exclude "NonHuman"), but again no papers made it through the screening process. Repeating the Stage 2 search returned a much larger number of studies in both Web of Science (4,573; Basic search of Topic, refined by "Human" within results) and Scopus $(6,616$; Advanced search of TitleAbstract, filter: include human and humans, exclude nonhumans, Articles only), with 8,604 unique records. This large number of records is too many to currently screen and may harbour further examples of SA loci in humans, but it is noteworthy that the majority of the initial list of studies found during Stage 2 using PubMed were also found in the other two databases (712 out of 881 ) as well as 28 out of the screened list of 32 studies identified in the current systematic review.

The disparity between the two stages of the review process provides a remarkable example of how discipline-specific terminology and concepts can hinder scientific communication between fields for substantial periods of time. For many of the studies identified in this review, the focus of the research was not on quantifying or even identifying sex-specific genetic effects in traits or disease, although they were tested for. The responses to such findings varied. Some framed these results as a major finding, others merely made note of them, with one suggesting that since the genetic associations were in opposite directions in the two sexes then it should be regarded as a false positive (Wong et al., 2005). It is possible, or even likely then that there exists a publication bias in the biomedical sciences against studies with apparently incongruous sex-opposite or SA effects, perhaps in part because the evolutionary framework that may provide a context for understanding those results is not generally appreciated or known. Of course, for evolutionary biologists interested in the role of SA selection on human traits and disease, this is clearly a problem. For many years no specific examples of SA loci were known in humans, and yet the first putative 
medRxiv preprint doi: https://doi.org/10.1101/2020.12.16.20248300; this version posted February 12,2021 . The copyright holder for this preprint (which was not certified by peer review) is the author/funder, who has granted medRxiv a license to display the preprint in It is made available under a CC-BY-NC 4.0 International license.

398

399

400

401

402

403

404

405

406

407

408

409

410

411

412

413

414

415

416

417

418

419

420

421

422

\section{Competing Interest Statement}

424 The authors have declared no competing interest. neighbouring field. some human diseases.

\section{Acknowledgements}

examples in fact appeared in the literature two decades ago. Our systematic review therefore provides a concrete illustration of how advances to both fields have likely been hampered by a limited understanding of the theoretical framework and terminology used by the

How can communication between the fields of medicine and evolutionary biology be facilitated? We do not have a comprehensive answer but clearly training in, or an increased awareness of, evolutionary medicine for scientists in both camps would probably be beneficial. The topic of evolutionary biology now forms a key part of the education for some biomedical scientists and clinicians. Similarly, evolutionary medicine is now frequently included in fundamental textbooks on evolution, and is being taught to students of evolutionary biology as part of their degree courses. These changes have been relatively recent, are far from being universally employed, but they should be encouraged. Funders of primary research are also now actively encouraging or obliging researchers to include sex as a factor when designing their studies (Clayton and Collins, 2014), although this may simply result in studies that aim to control for rather than investigate these effects explicitly. Consequently even this remedy may still preclude a deeper understanding of the origins of

We thank Jessica Abbott, Tim Connallon and Filip Ruzicka for comments on a previous version of the MS. Funding was provided by the Swedish Research Council (Grant number: 201903567) and by the Royal Society to EHM as a University Research Fellowship and Enhancement Award. TJ was funded by the Centre national de la recherche scientifique (CNRS) and the German Research Foundation (DFG grant number: JA 2653/2-1).

425 
medRxiv preprint doi: https://doi.org/10.1101/2020.12.16.20248300; this version posted February $12,2021$. The copyright holder for this preprint (which was not certified by peer review) is the author/funder, who has granted medRxiv a license to display the preprint in perpetuity.

It is made available under a CC-BY-NC 4.0 International license.

\section{References}

427

428

429

430

431

432

433

434

435

436

437

438

439

440

441

442

443

444

445

446

447

448

449

450

451

452

453

454

455

456

457

458

459

460

461

462

463

464

465

466

467

468

469

470

471

Albers, P.K., McVean, G., 2018. Dating genomic variants and shared ancestry in populationscale sequencing data (preprint). Genomics. https://doi.org/10.1101/416610

Auton, A., Abecasis, G.R., Altshuler, D.M., Durbin, R.M., Abecasis, G.R., Bentley, D.R., Chakravarti, A., Clark, A.G., Donnelly, P., Eichler, E.E., Flicek, P., Gabriel, S.B., Gibbs, R.A., Green, E.D., Hurles, M.E., Knoppers, B.M., Korbel, J.O., Lander, E.S., Lee, C., Lehrach, H., Mardis, E.R., Marth, G.T., McVean, G.A., Nickerson, D.A., Schmidt, J.P., Sherry, S.T., Wang, J., Wilson, R.K., Gibbs, R.A., Boerwinkle, E., Doddapaneni, H., Han, Y., Korchina, V., Kovar, C., Lee, S., Muzny, D., Reid, J.G., Zhu, Y., Wang, J., Chang, Y., Feng, Q., Fang, X., Guo, X., Jian, M., Jiang, H., Jin, X., Lan, T., Li, G., Li, J., Li, Y., Liu, S., Liu, X., Lu, Y., Ma, X., Tang, M., Wang, B., Wang, G., Wu, H., Wu, R., Xu, X., Yin, Y., Zhang, D., Zhang, W., Zhao, J., Zhao, M., Zheng, X., Lander, E.S., Altshuler, D.M., Gabriel, S.B., Gupta, N., Gharani, N., Toji, L.H., Gerry, N.P., Resch, A.M., Flicek, P., Barker, J., Clarke, L., Gil, L., Hunt, S.E., Kelman, G., Kulesha, E., Leinonen, R., McLaren, W.M., Radhakrishnan, R., Roa, A., Smirnov, D., Smith, R.E., Streeter, I., Thormann, A., Toneva, I., Vaughan, B., Zheng-Bradley, X., Bentley, D.R., Grocock, R., Humphray, S., James, T., Kingsbury, Z., Lehrach, H., Sudbrak, R., Albrecht, M.W., Amstislavskiy, V.S., Borodina, T.A., Lienhard, M., Mertes, F., Sultan, M., Timmermann, B., Yaspo, M.-L., Mardis, E.R., Wilson, R.K., Fulton, L., Fulton, R., Sherry, S.T., Ananiev, V., Belaia, Z., Beloslyudtsev, D., Bouk, N., Chen, C., Church, D., Cohen, R., Cook, C., Garner, J., Hefferon, T., Kimelman, M., Liu, C., Lopez, J., Meric, P., O’Sullivan, C., Ostapchuk, Y., Phan, L., Ponomarov, S., Schneider, V., Shekhtman, E., Sirotkin, K., Slotta, D., Zhang, H., McVean, G.A., Durbin, R.M., Balasubramaniam, S., Burton, J., Danecek, P., Keane, T.M., Kolb-Kokocinski, A., McCarthy, S., Stalker, J., Quail, M., Schmidt, J.P., Davies, C.J., Gollub, J., Webster, T., Wong, B., Zhan, Y., Auton, A., Campbell, C.L., Kong, Y., Marcketta, A., Gibbs, R.A., Yu, F., Antunes, L., Bainbridge, M., Muzny, D., Sabo, A., Huang, Z., Wang, J., Coin, L.J.M., Fang, L., Guo, X., Jin, X., Li, G., Li, Q., Li, Y., Li, Z., Lin, H., Liu, B., Luo, R., Shao, H., Xie, Y., Ye, C., Yu, C., Zhang, F., Zheng, H., Zhu, H., Alkan, C., Dal, E., Kahveci, F., Marth, G.T., Garrison, E.P., Kural, D., Lee, W.-P., Fung Leong, W., Stromberg, M., Ward, A.N., Wu, J., Zhang, M., Daly, M.J., DePristo, M.A., Handsaker, R.E., Altshuler, D.M., Banks, E., Bhatia, G., del Angel, G., Gabriel, S.B., Genovese, G., Gupta, N., Li, H., Kashin, S., Lander, E.S., McCarroll, S.A., Nemesh, J.C., Poplin, R.E., Yoon, S.C., Lihm, J., Makarov, V., Clark, A.G., Gottipati, S., Keinan, A., Rodriguez-Flores, J.L., Korbel, J.O., Rausch, T., Fritz, M.H., Stütz, A.M., Flicek, P., Beal, K., Clarke, L., Datta, A., Herrero, J., McLaren, W.M., Ritchie, G.R.S., Smith, R.E., Zerbino, D., Zheng-Bradley, X., Sabeti, P.C., Shlyakhter, I., Schaffner, S.F., Vitti, J., Cooper, D.N., Ball, E.V., Stenson, P.D., Bentley, D.R., Barnes, B., Bauer, M., Keira Cheetham, R., Cox, A., Eberle, M., Humphray, S., Kahn, S., Murray, L., Peden, J., Shaw, R., Kenny, E.E., Batzer, M.A., Konkel, M.K., Walker, J.A., MacArthur, D.G., Lek, M., Sudbrak, R., Amstislavskiy, V.S., Herwig, R., Mardis, E.R., Ding, L., Koboldt, D.C., Larson, D., Ye, K., Gravel, S., The 1000 Genomes Project Consortium, Corresponding authors, Steering committee, Production group, Baylor College of Medicine, BGIShenzhen, Broad Institute of MIT and Harvard, Coriell Institute for Medical Research, European Molecular Biology Laboratory, E.B.I., Illumina, Max Planck Institute for Molecular Genetics, McDonnell Genome Institute at Washington University, US National Institutes of Health, University of Oxford, Wellcome Trust Sanger Institute, 
medRxiv preprint doi: https://doi.org/10.1101/2020.12.16.20248300; this version posted February $12,2021$. The copyright holder for this preprint (which was not certified by peer review) is the author/funder, who has granted medRxiv a license to display the preprint in perpetuity.

It is made available under a CC-BY-NC 4.0 International license .

Analysis group, Affymetrix, Albert Einstein College of Medicine, Bilkent University, Boston College, Cold Spring Harbor Laboratory, Cornell University, European Molecular Biology Laboratory, Harvard University, Human Gene Mutation Database, Icahn School of Medicine at Mount Sinai, Louisiana State University, Massachusetts General Hospital, McGill University, National Eye Institute, N., 2015. A global reference for human genetic variation. Nature 526, 68-74. https://doi.org/10.1038/nature15393

Barson, N.J., Aykanat, T., Hindar, K., Baranski, M., Bolstad, G.H., Fiske, P., Jacq, C., Jensen, A.J., Johnston, S.E., Karlsson, S., Kent, M., Moen, T., Niemelä, E., Nome, T., Næsje, T.F., Orell, P., Romakkaniemi, A., Sægrov, H., Urdal, K., Erkinaro, J., Lien, S., Primmer, C.R., 2015. Sex-dependent dominance at a single locus maintains variation in age at maturity in salmon. Nature 528, 405-408. https://doi.org/10.1038/nature16062

Bonduriansky, R., Chenoweth, S.F., 2009. Intralocus sexual conflict. Trends Ecol Evol 24, 280-288.

Borenstein, M., 2009. Converting Among Effect Sizes, in: Introduction to Meta-Analysis. John Wiley \& Sons, Ltd, pp. 45-49. https://doi.org/10.1002/9780470743386.ch7

Camus, M.F., Wolf, J.B.W., Morrow, E.H., Dowling, D.K., 2015. Single Nucleotides in the mtDNA Sequence Modify Mitochondrial Molecular Function and Are Associated with Sex-Specific Effects on Fertility and Aging. Curr. Biol. 25, 2717-2722. https://doi.org/10.1016/j.cub.2015.09.012

Carlson, J.C., Nidey, N.L., Butali, A., Buxo, C.J., Christensen, K., Deleyiannis, F.W.-D., Hecht, J.T., Field, L.L., Moreno-Uribe, L.M., Orioli, I.M., Poletta, F.A., Padilla, C., Vieira, A.R., Weinberg, S.M., Wehby, G.L., Feingold, E., Murray, J.C., Marazita, M.L., Leslie, E.J., 2018. Genome-wide interaction studies identify sex-specific risk alleles for nonsyndromic orofacial clefts. Genet. Epidemiol. 42, 664-672. https://doi.org/10.1002/gepi.22158

Chippindale, A.K., Gibson, J.R., Rice, W.R., 2001. Negative genetic correlation for adult fitness between sexes reveals ontogenetic conflict in Drosophila. Proc. Natl. Acad. Sci. USA 98, 1671-1675.

Cicchetti, D., Rogosch, F.A., Hecht, K.F., Crick, N.R., Hetzel, S., 2014. Moderation of maltreatment effects on childhood borderline personality symptoms by gender and oxytocin receptor and FK506 binding protein 5 genes. Dev. Psychopathol. 26, 831849. https://doi.org/10.1017/S095457941400042X

Clayton, J.A., Collins, F.S., 2014. Policy: NIH to balance sex in cell and animal studies. Nature 509, 282-283. https://doi.org/10.1038/509282a

Connallon, T., Clark, A., G., 2014. Evolutionary inevitability of sexual antagonism. Proc. R. Soc. B Biol. Sci. 281, 20132123. https://doi.org/10.1098/rspb.2013.2123

Connallon, T., Clark, A.G., 2013. Antagonistic Versus Nonantagonistic Models of Balancing Selection: Characterizing the Relative Timescales and Hitchhiking Effects of Partial Selective Sweeps. Evolution 67, 908-917. https://doi.org/10.1111/j.15585646.2012.01800.x

Dauvilliers, Y., Neidhart, E., Lecendreux, M., Billiard, M., Tafti, M., 2001. MAO-A and COMT polymorphisms and gene effects in narcolepsy. Mol. Psychiatry 6, 367-372. https://doi.org/10.1038/sj.mp.4000911

Dixson, A., 2009. Dixson, A. F. (2009) Sexual selection and the Origins of Human Mating Systems. Oxford University Press, UK. 
medRxiv preprint doi: https://doi.org/10.1101/2020.12.16.20248300; this version posted February $12,2021$. The copyright holder for this preprint (which was not certified by peer review) is the author/funder, who has granted medRxiv a license to display the preprint in perpetuity.

It is made available under a CC-BY-NC 4.0 International license .

Ellegren, H., Parsch, J., 2007. The evolution of sex-biased genes and sex-biased gene expression. Nat Rev Genet 8, 689-698. https://doi.org/10.1038/nrg2167

Fillingim, R.B., Kaplan, L., Staud, R., Ness, T.J., Glover, T.L., Campbell, C.M., Mogil, J.S., Wallace, M.R., 2005. The A118G single nucleotide polymorphism of the mu-opioid receptor gene (OPRM1) is associated with pressure pain sensitivity in humans. J. Pain Off. J. Am. Pain Soc. 6, 159-167. https://doi.org/10.1016/j.jpain.2004.11.008

Fitzpatrick, M.J., 2004. Pleiotropy and the genomic location of sexually selected genes. Am. Nat. 163, 800-808. https://doi.org/10.1086/386297

Foerster, K., Coulson, T., Sheldon, B.C., Pemberton, J.M., Clutton-Brock, T., Kruuk, L.E.B., 2007. Sexually antagonistic genetic variation for fitness in red deer. Nature 447, 1107-1110.

Franck, N., Lanne, T., Astrand, O., Engvall, J., Lindstrom, T., Ostgren, C.J., Nystrom, F.H., 2012. Cardiovascular risk factors related to the PPARgamma Pro12Ala polymorphism in patients with type 2 diabetes are gender dependent. Blood Press. 21, 122-127. https://doi.org/10.3109/08037051.2011.623349

Fry, J.D., 2010. The Genomic Location of Sexually Antagonistic Variation: Some Cautionary Comments. Evolution 64, 1510-1516. https://doi.org/10.1111/j.15585646.2009.00898.x

Garver-Apgar, C.E., Eaton, M.A., Tybur, J.M., Emery Thompson, M., 2011. Evidence of intralocus sexual conflict: physically and hormonally masculine individuals have more attractive brothers relative to sisters. Evol. Hum. Behav. 32, 423-432. https://doi.org/10.1016/j.evolhumbehav.2011.03.005

Gastaldi, M., Diziere, S., Defoort, C., Portugal, H., Lairon, D., Darmon, M., Planells, R., 2007. Sex-specific association of fatty acid binding protein 2 and microsomal triacylglycerol transfer protein variants with response to dietary lipid changes in the 3-mo MediRIVAGE primary intervention study. Am. J. Clin. Nutr. 86, 1633-1641. https://doi.org/10.1093/ajcn/86.5.1633

Gilks, W.P., Abbott, J.K., Morrow, E.H., 2014. Sex differences in disease genetics: evidence, evolution, and detection. Trends Genet. 30, 453-463. https://doi.org/10.1016/j.tig.2014.08.006

Gloria-Bottini, F., Bottini, N., Renzetti, G., Bottini, E., 2007. ACP1 and Th class of immunological disease: evidence of interaction with gender. Int. Arch. Allergy Immunol. 143, 170-176. https://doi.org/10.1159/000099308

Grieshop, K., Arnqvist, G., 2018. Sex-specific dominance reversal of genetic variation for fitness. PLOS Biol. 16, e2006810. https://doi.org/10.1371/journal.pbio.2006810

Gurevitch, J., Koricheva, J., Mengersen, K., 2013. Handbook of Meta-Analysis In Ecology and Evolution, Handbook of Meta-analysis in Ecology and Evolution. https://doi.org/10.1515/9781400846184

Herman, A.I., Conner, T.S., Anton, R.F., Gelernter, J., Kranzler, H.R., Covault, J., 2011. Variation in the gene encoding the serotonin transporter is associated with a measure of sociopathy in alcoholics. Addict. Biol. 16, 124-132. https://doi.org/10.1111/j.1369-1600.2009.00197.x

Khramtsova, E.A., Davis, L.K., Stranger, B.E., 2019. The role of sex in the genomics of human complex traits. Nat. Rev. Genet. 20, 173-190. https://doi.org/10.1038/s41576-0180083-1 
medRxiv preprint doi: https://doi.org/10.1101/2020.12.16.20248300; this version posted February $12,2021$. The copyright holder for this preprint (which was not certified by peer review) is the author/funder, who has granted medRxiv a license to display the preprint in perpetuity.

It is made available under a CC-BY-NC 4.0 International license .

563

564

565

566

567

568

569

570

571

572

573

574

575

576

577

578

579

580

581

582

583

584

585

586

587

588

589

590

591

592

593

594

595

596

597

598

599

600

601

602

603

604

605

606

607

608
Kim, B., Kim, H., Joo, Y.H., Lim, J., Kim, C.-Y., Song, K., 2010. Sex-different association of DAO with schizophrenia in Koreans. Psychiatry Res. 179, 121-125. https://doi.org/10.1016/j.psychres.2008.08.009

Kiy, A., Wilhelm, O., Hildebrandt, A., Reuter, M., Sommer, W., 2013. On the genetic basis of face cognition and its relation to fluid cognitive abilities. Genes Brain Behav. 12, 438445. https://doi.org/10.1111/gbb.12034

Korner, A., Ma, L., Franks, P.W., Kiess, W., Baier, L.J., Stumvoll, M., Kovacs, P., 2007. Sexspecific effect of the Val1483lle polymorphism in the fatty acid synthase gene (FAS) on body mass index and lipid profile in Caucasian children. Int. J. Obes. 2005 31, 353-358. https://doi.org/10.1038/sj.ijo.0803428

Lajeunesse, M., 2013. Recovering missing or partial data from studies: A survey of conversions and imputations for meta-analysis. pp. 195-206.

Lande, R., 1980. Sexual dimorphism, sexual selection, and adaptation in polygenic characters. Evolution 34, 292-305.

Lang, U.E., Hellweg, R., Bajbouj, M., Gaus, V., Sander, T., Gallinat, J., 2008. Genderdependent association of a functional NGF polymorphism with anxiety-related personality traits. Pharmacopsychiatry 41, 196-199. https://doi.org/10.1055/s-00281082070

Lauritzen, L., Sorensen, L.B., Harslof, L.B., Ritz, C., Stark, K.D., Astrup, A., Dyssegaard, C.B., Egelund, N., Michaelsen, K.F., Damsgaard, C.T., 2017. Mendelian randomization shows sex-specific associations between long-chain. Am. J. Clin. Nutr. 106, 88-95. https://doi.org/10.3945/ajcn.117.152595

Lee, S.K., 2018. Sex as an important biological variable in biomedical research. BMB Rep. 51, 167-173. https://doi.org/10.5483/BMBRep.2018.51.4.034

Liu, Y.-H., Chen, Y.-J., Wu, H.-H., Wang, T.-Y., Tsai, F.-J., 2014. Single nucleotide polymorphisms at the PRR3, ABCF1, and GNL1 genes in the HLA class I region are associated with Graves' ophthalmopathy in a gender-dependent manner. Ophthalmology 121, 2033-2039. https://doi.org/10.1016/j.ophtha.2014.04.027

Ljungberg, L.U., Ostgren, C.J., Nystrom, F.H., Lanne, T., 2014. Associations of genetic polymorphisms in the renin-angiotensin system with central aortic and ambulatory blood pressure in type 2 diabetic patients. J. Renin-Angiotensin-Aldosterone Syst. JRAAS 15, 61-68. https://doi.org/10.1177/1470320312474052

McCarthy, J.J., Somji, A., Weiss, L.A., Steffy, B., Vega, R., Barrett-Connor, E., Talavera, G., Glynne, R., 2009. Polymorphisms of the scavenger receptor class B member 1 are associated with insulin resistance with evidence of gene by sex interaction. J. Clin. Endocrinol. Metab. 94, 1789-1796. https://doi.org/10.1210/jc.2008-2800

Mills, S.C., Koskela, E., Mappes, T., 2011. Intralocus sexual conflict for fitness: sexually antagonistic alleles for testosterone. Proc. R. Soc. B Biol. Sci. rspb20112340. https://doi.org/10.1098/rspb.2011.2340

Moher, D., Liberati, A., Tetzlaff, J., Altman, D.G., Group, T.P., 2009. Preferred Reporting Items for Systematic Reviews and Meta-Analyses: The PRISMA Statement. PLOS Med. 6, e1000097. https://doi.org/10.1371/journal.pmed.1000097

Morea, A., Cameran, M., Rebuffi, A.G., Marzenta, D., Marangon, O., Picci, L., Zacchello, F., Scarpa, M., 2005. Gender-sensitive association of CFTR gene mutations and 5 T allele emerging from a large survey on infertility. Mol. Hum. Reprod. 11, 607-614. https://doi.org/10.1093/molehr/gah214 
medRxiv preprint doi: https://doi.org/10.1101/2020.12.16.20248300; this version posted February $12,2021$. The copyright holder for this preprint (which was not certified by peer review) is the author/funder, who has granted medRxiv a license to display the preprint in perpetuity.

It is made available under a CC-BY-NC 4.0 International license .

609

610

611

612

613

614

615

616

617

618

619

620

621

622

623

624

625

626

627

628

629

630

631

632

633

634

635

636

637

638

639

640

641

642

643

644

645

646

647

648

649

650

651

652

653

654

655
Morrow, E.H., 2015. The evolution of sex differences in disease. Biol. Sex Differ. 6, 5. https://doi.org/10.1186/s13293-015-0023-0

Morrow, E.H., Connallon, T., 2013. Implications of sex-specific selection for the genetic basis of disease. Evol. Appl. 6, 1208-1217. https://doi.org/10.1111/eva.12097

Nesse, R.M., Williams, G.C., 1994. Why we get sick: The new science of Darwinian medicine. Vintage, New York.

Ober, C., Loisel, D.A., Gilad, Y., 2008. Sex-specific genetic architecture of human disease. Nat Rev Genet 9, 911-922. https://doi.org/10.1038/nrg2415

Ober, C., Pan, L., Phillips, N., Parry, R., Kurina, L.M., 2006. Sex-specific genetic architecture of asthma-associated quantitative trait loci in a founder population. Curr. Allergy Asthma Rep. 6, 241-246. https://doi.org/10.1007/s11882-006-0041-4

Ovadia, G., Shifman, S., 2011. The genetic variation of RELN expression in schizophrenia and bipolar disorder. PloS One 6, e19955. https://doi.org/10.1371/journal.pone.0019955

Padmanabhan, S., Menni, C., Lee, W.K., Laing, S., Brambilla, P., Sega, R., Perego, R., Grassi, G., Cesana, G., Delles, C., Mancia, G., Dominiczak, A.F., 2010. The effects of sex and method of blood pressure measurement on genetic associations with blood pressure in the PAMELA study. J. Hypertens. 28, 465-477.

https://doi.org/10.1097/HJH.0b013e32833594d7

Parker, G.A., 1979. SEXUAL SELECTION AND SEXUAL CONFLICT, in: Sexual Selection and Reproductive Competition in Insects. Elsevier, pp. 123-166. https://doi.org/10.1016/B978-0-12-108750-0.50010-0

Parker, G.A., Baker, R.R., Smith, V.G.F., 1972. The origin and evolution of gamete dimorphism and the male-female phenomenon. J. Theor. Biol. 36, 529-553.

Payne, E.H., Gebregziabher, M., Hardin, J.W., Ramakrishnan, V., Egede, L.E., 2018. An empirical approach to determine a threshold for assessing overdispersion in Poisson and negative binomial models for count data. Commun. Stat. Simul. Comput. 47, 1722-1738. https://doi.org/10.1080/03610918.2017.1323223

Peng, Y.-M., Lei, S.-F., Guo, Y., Xiong, D.-H., Yan, H., Wang, L., Guo, Y.-F., Deng, H.-W., 2008. Sex-specific association of the glucocorticoid receptor gene with extreme BMD. J. Bone Miner. Res. Off. J. Am. Soc. Bone Miner. Res. 23, 247-252. https://doi.org/10.1359/jbmr.071017

Pennell, T.M., Haas, F.J.H. de, Morrow, E.H., Doorn, G.S. van, 2016. Contrasting effects of intralocus sexual conflict on sexually antagonistic coevolution. Proc. Natl. Acad. Sci. 113, E978-E986. https://doi.org/10.1073/pnas.1514328113

Pennell, T.M., Morrow, E.H., 2013. Two sexes, one genome: the evolutionary dynamics of intralocus sexual conflict. Ecol. Evol. 3, 1819-1834. https://doi.org/10.1002/ece3.540

Press, O.A., Zhang, W., Gordon, M.A., Yang, D., Haiman, C.A., Azuma, M., Iqbal, S., Lenz, H.J., 2011. Gender-related survival differences associated with polymorphic variants of estrogen receptor-beta (ERbeta) in patients with metastatic colon cancer. Pharmacogenomics J. 11, 375-382. https://doi.org/10.1038/tpj.2010.45

Price, J.S., Strong, J., Eliassen, J., McQueeny, T., Miller, M., Padula, C.B., Shear, P., Lisdahl, K., 2013. Serotonin transporter gene moderates associations between mood, memory and hippocampal volume. Behav. Brain Res. 242, 158-165.

https://doi.org/10.1016/j.bbr.2012.11.013

Rice, W.R., 1992. Sexually antagonistic genes: experimental evidence. Science 256, 14361439. https://doi.org/10.1126/science.1604317 
medRxiv preprint doi: https://doi.org/10.1101/2020.12.16.20248300; this version posted February $12,2021$. The copyright holder for this preprint (which was not certified by peer review) is the author/funder, who has granted medRxiv a license to display the preprint in perpetuity.

It is made available under a CC-BY-NC 4.0 International license .

656

657

658

659

660

661

662

663

664

665

666

667

668

669

670

671

672

673

674

675

676

677

678

679

680

681

682

683

684

685

686

687

688

689

690

691

692

693

694

695

696

697

698

699

700

701

702
Rice, W.R., 1984. Sex chromosomes and the evolution of sexual dimorphism. Evolution 38, 735-742.

Rigby, N., Kulathinal, R.J., 2015. Genetic Architecture of Sexual Dimorphism in Humans. J. Cell. Physiol. 230, 2304-2310. https://doi.org/10.1002/jcp.24979

Rostant, W.G., Kay, C., Wedell, N., Hosken, D.J., 2015. Sexual conflict maintains variation at an insecticide resistance locus. BMC Biol. 13. https://doi.org/10.1186/s12915-0150143-3

Ruzicka, F., Connallon, T., 2020. Is the X chromosome a hot spot for sexually antagonistic polymorphisms? Biases in current empirical tests of classical theory. Proc. R. Soc. B. https://doi.org/10.1098/rspb.2020.1869

Ruzicka, F., Dutoit, L., Czuppon, P., Jordan, C.Y., Li, X.-Y., Olito, C., Runemark, A., Svensson, E.I., Yazdi, H.P., Connallon, T., 2020. The search for sexually antagonistic genes: Practical insights from studies of local adaptation and statistical genomics. Evol. Lett. 4-5, 398-415. https://doi.org/10.1002/evl3.192

Ruzicka, F., Hill, M.S., Pennell, T.M., Flis, I., Ingleby, F.C., Mott, R., Fowler, K., Morrow, E.H., Reuter, M., 2019. Genome-wide sexually antagonistic variants reveal long-standing constraints on sexual dimorphism in fruit flies. PLoS Biol. 17, e3000244.

Sainz, J., Rudolph, A., Hoffmeister, M., Frank, B., Brenner, H., Chang-Claude, J., Hemminki, K., Forsti, A., 2012. Effect of type 2 diabetes predisposing genetic variants on colorectal cancer risk. J. Clin. Endocrinol. Metab. 97, E845-851. https://doi.org/10.1210/jc.2011-2565

Sangalli, A., Orlandi, E., Poli, A., Maurichi, A., Santinami, M., Nicolis, M., Ferronato, S., Malerba, G., Rodolfo, M., Gomez Lira, M., 2017. Sex-specific effect of RNASEL rs486907 and miR-146a rs2910164 polymorphisms' interaction as a susceptibility factor for melanoma skin cancer. Melanoma Res. 27, 309-314. https://doi.org/10.1097/CMR.0000000000000360

Schneider, K.K., Hule, L., Schote, A.B., Meyer, J., Frings, C., 2015. Sex matters! Interactions of sex and polymorphisms of a cholinergic receptor gene (CHRNA5) modulate response speed. Neuroreport 26, 186-191. https://doi.org/10.1097/WNR.0000000000000313

Schuurhof, A., Bont, L., Siezen, C.L.E., Hodemaekers, H., van Houwelingen, H.C., Kimman, T.G., Hoebee, B., Kimpen, J.L.L., Janssen, R., 2010. Interleukin-9 polymorphism in infants with respiratory syncytial virus infection: an opposite effect in boys and girls. Pediatr. Pulmonol. 45, 608-613. https://doi.org/10.1002/ppul.21229

Shalev, I., Lerer, E., Israel, S., Uzefovsky, F., Gritsenko, I., Mankuta, D., Ebstein, R.P., Kaitz, M., 2009. BDNF Val66Met polymorphism is associated with HPA axis reactivity to psychological stress characterized by genotype and gender interactions. Psychoneuroendocrinology 34, 382-388. https://doi.org/10.1016/j.psyneuen.2008.09.017

Short, R.V., 1979. Sexual selection and its component parts, somatic and genital selection, as illustrated by man and the great apes. Adv. Study Behav. 9, 131-158.

Sjoberg, R.L., Nilsson, K.W., Nordquist, N., Ohrvik, J., Leppert, J., Lindstrom, L., Oreland, L., 2006. Development of depression: sex and the interaction between environment and a promoter polymorphism of the serotonin transporter gene. Int. J. Neuropsychopharmacol. 9, 443-449. https://doi.org/10.1017/S1461145705005936

Stearns, S.C., Govindaraju, D.R., Ewbank, D., Byars, S.G., 2012. Constraints on the coevolution of contemporary human males and females. Proc. R. Soc. B Biol. Sci. 279, 4836-4844. https://doi.org/10.1098/rspb.2012.2024 
Stulp, G., Kuijper, B., Buunk, A.P., Pollet, T.V., Verhulst, S., 2012. Intralocus sexual conflict over human height. Biol. Lett. https://doi.org/10.1098/rsbl.2012.0590

Winkler, T.W., Justice, A.E., Graff, M., Barata, L., Feitosa, M.F., Chu, S., Czajkowski, J., Esko, T., Fall, T., Kilpeläinen, T.O., Lu, Y., Mägi, R., Mihailov, E., Pers, T.H., Rüeger, S., Teumer, A., Ehret, G.B., Ferreira, T., Heard-Costa, N.L., Karjalainen, J., Lagou, V., Mahajan, A., Neinast, M.D., Prokopenko, I., Simino, J., Teslovich, T.M., Jansen, R., Westra, H.-J., White, C.C., Absher, D., Ahluwalia, T.S., Ahmad, S., Albrecht, E., Alves, A.C., Bragg-Gresham, J.L., Craen, A.J.M. de, Bis, J.C., Bonnefond, A., Boucher, G., Cadby, G., Cheng, Y.-C., Chiang, C.W.K., Delgado, G., Demirkan, A., Dueker, N., Eklund, N., Eiriksdottir, G., Eriksson, J., Feenstra, B., Fischer, K., Frau, F., Galesloot, T.E., Geller, F., Goel, A., Gorski, M., Grammer, T.B., Gustafsson, S., Haitjema, S., Hottenga, J.-J., Huffman, J.E., Jackson, A.U., Jacobs, K.B., Johansson, Å., Kaakinen, M., Kleber, M.E., Lahti, J., Leach, I.M., Lehne, B., Liu, Y., Lo, K.S., Lorentzon, M., Luan, J., Madden, P.A.F., Mangino, M., McKnight, B., Medina-Gomez, C., Monda, K.L., Montasser, M.E., Müller, G., Müller-Nurasyid, M., Nolte, I.M., Panoutsopoulou, K., Pascoe, L., Paternoster, L., Rayner, N.W., Renström, F., Rizzi, F., Rose, L.M., Ryan, K.A., Salo, P., Sanna, S., Scharnagl, H., Shi, J., Smith, A.V., Southam, L., Stančáková, A., Steinthorsdottir, V., Strawbridge, R.J., Sung, Y.J., Tachmazidou, I., Tanaka, T., Thorleifsson, G., Trompet, S., Pervjakova, N., Tyrer, J.P., Vandenput, L., Laan, S.W. van der, Velde, N. van der, Setten, J. van, Vliet-Ostaptchouk, J.V. van, Verweij, N., Vlachopoulou, E., Waite, L.L., Wang, S.R., Wang, Z., Wild, S.H., Willenborg, C., Wilson, J.F., Wong, A., Yang, J., Yengo, L., Yerges-Armstrong, L.M., Yu, L., Zhang, W., Zhao, J.H., Andersson, E.A., Bakker, S.J.L., Baldassarre, D., Banasik, K., Barcella, M., Barlassina, C., Bellis, C., Benaglio, P., Blangero, J., Blüher, M., Bonnet, F., Bonnycastle, L.L., Boyd, H.A., Bruinenberg, M., Buchman, A.S., Campbell, H., Chen, Y.-D.I., Chines, P.S., Claudi-Boehm, S., Cole, J., Collins, F.S., Geus, E.J.C. de, Groot, L.C.P.G.M. de, Dimitriou, M., Duan, J., Enroth, S., Eury, E., Farmaki, A.-E., Forouhi, N.G., Friedrich, N., Gejman, P.V., Gigante, B., Glorioso, N., Go, A.S., Gottesman, O., Gräßler, J., Grallert, H., Grarup, N., Gu, Y.-M., Broer, L., Ham, A.C., Hansen, T., Harris, T.B., Hartman, C.A., Hassinen, M., Hastie, N., Hattersley, A.T., Heath, A.C., Henders, A.K., Hernandez, D., Hillege, H., Holmen, O., Hovingh, K.G., Hui, J., Husemoen, L.L., Hutri-Kähönen, N., Hysi, P.G., Illig, T., Jager, P.L.D., Jalilzadeh, S., Jørgensen, T., Jukema, J.W., Juonala, M., Kanoni, S., Karaleftheri, M., Khaw, K.T., Kinnunen, L., Kittner, S.J., Koenig, W., Kolcic, I., Kovacs, P., Krarup, N.T., Kratzer, W., Krüger, J., Kuh, D., Kumari, M., Kyriakou, T., Langenberg, C., Lannfelt, L., Lanzani, C., Lotay, V., Launer, L.J., Leander, K., Lindström, J., Linneberg, A., Liu, Y.-P., Lobbens, S., Luben, R., Lyssenko, V., Männistö, S., Magnusson, P.K., McArdle, W.L., Menni, C., Merger, S., Milani, L., Montgomery, G.W., Morris, A.P., Narisu, N., Nelis, M., Ong, K.K., Palotie, A., Pérusse, L., Pichler, I., Pilia, M.G., Pouta, A., Rheinberger, M., Ribel-Madsen, R., Richards, M., Rice, K.M., Rice, T.K., Rivolta, C., Salomaa, V., Sanders, A.R., Sarzynski, M.A., Scholtens, S., Scott, R.A., Scott, W.R., Sebert, S., Sengupta, S., Sennblad, B., Seufferlein, T., Silveira, A., Slagboom, P.E., Smit, J.H., Spars $\varnothing$, T.H., Stirrups, K., Stolk, R.P., Stringham, H.M., Swertz, M.A., Swift, A.J., Syvänen, A.-C., Tan, S.-T., Thorand, B., Tönjes, A., Tremblay, A., Tsafantakis, E., Most, P.J. van der, Völker, U., Vohl, M.-C., Vonk, J.M., Waldenberger, M., Walker, R.W., Wennauer, R., Widén, E., Willemsen, G., Wilsgaard, T., Wright, A.F., Zillikens, M.C., Dijk, S.C. van, Schoor, N.M. van, Asselbergs, F.W., Bakker, P.I.W. de, Beckmann, J.S., Beilby, J., Bennett, D.A., 
Bergman, R.N., Bergmann, S., Böger, C.A., Boehm, B.O., Boerwinkle, E., Boomsma, D.I., Bornstein, S.R., Bottinger, E.P., Bouchard, C., Chambers, J.C., Chanock, S.J., Chasman, D.I., Cucca, F., Cusi, D., Dedoussis, G., Erdmann, J., Eriksson, J.G., Evans, D.A., Faire, U. de, Farrall, M., Ferrucci, L., Ford, I., Franke, L., Franks, P.W., Froguel, P., Gansevoort, R.T., Gieger, C., Grönberg, H., Gudnason, V., Gyllensten, U., Hall, P., Hamsten, A., Harst, P. van der, Hayward, C., Heliövaara, M., Hengstenberg, C., Hicks, A.A., Hingorani, A., Hofman, A., Hu, F., Huikuri, H.V., Hveem, K., James, A.L., Jordan, J.M., Jula, A., Kähönen, M., Kajantie, E., Kathiresan, S., Kiemeney, L.A.L.M., Kivimaki, M., Knekt, P.B., Koistinen, H.A., Kooner, J.S., Koskinen, S., Kuusisto, J., Maerz, W., Martin, N.G., Laakso, M., Lakka, T.A., Lehtimäki, T., Lettre, G., Levinson, D.F., Lind, L., Lokki, M.-L., Mäntyselkä, P., Melbye, M., Metspalu, A., Mitchell, B.D., Moll, F.L., Murray, J.C., Musk, A.W., Nieminen, M.S., Njølstad, I., Ohlsson, C., Oldehinkel, A.J., Oostra, B.A., Palmer, L.J., Pankow, J.S., Pasterkamp, G., Pedersen, N.L., Pedersen, O., Penninx, B.W., Perola, M., Peters, A., Polašek, O., Pramstaller, P.P., Psaty, B.M., Qi, L., Quertermous, T., Raitakari, O.T., Rankinen, T., Rauramaa, R., Ridker, P.M., Rioux, J.D., Rivadeneira, F., Rotter, J.I., Rudan, I., Ruijter, H.M. den, Saltevo, J., Sattar, N., Schunkert, H., Schwarz, P.E.H., Shuldiner, A.R., Sinisalo, J., Snieder, H., Sørensen, T.I.A., Spector, T.D., Staessen, J.A., Stefania, B., Thorsteinsdottir, U., Stumvoll, M., Tardif, J.-C., Tremoli, E., Tuomilehto, J., Uitterlinden, A.G., Uusitupa, M., Verbeek, A.L.M., Vermeulen, S.H., Viikari, J.S., Vitart, V., Völzke, H., Vollenweider, P., Waeber, G., Walker, M., Wallaschofski, H., Wareham, N.J., Watkins, H., Zeggini, E., Consortium, C., Consortium, D., Consortium, G., Consortium, G.-Bpg., Consortium, I., Consortium, M., Chakravarti, A., Clegg, D.J., Cupples, L.A., Gordon-Larsen, P., Jaquish, C.E., Rao, D.C., Abecasis, G.R., Assimes, T.L., Barroso, I., Berndt, S.I., Boehnke, M., Deloukas, P., Fox, C.S., Groop, L.C., Hunter, D.J., Ingelsson, E., Kaplan, R.C., McCarthy, M.I., Mohlke, K.L., O'Connell, J.R., Schlessinger, D., Strachan, D.P., Stefansson, K., Duijn, C.M. van, Hirschhorn, J.N., Lindgren, C.M., Heid, I.M., North, K.E., Borecki, I.B., Kutalik, Z., Loos, R.J.F., 2015. The Influence of Age and Sex on Genetic Associations with Adult Body Size and Shape: A Large-Scale Genome-Wide Interaction Study. PLOS Genet. 11, e1005378. https://doi.org/10.1371/journal.pgen.1005378

Wise, A.L., Gyi, L., Manolio, T.A., 2013. eXclusion: Toward Integrating the $X$ Chromosome in Genome-wide Association Analyses. Am. J. Hum. Genet. 92, 643-647. https://doi.org/10.1016/j.ajhg.2013.03.017

Wong, S.Y.S., Lau, E.M.C., Li, M., Chung, T., Sham, A., Woo, J., 2005. The prevalence of Apo E4 genotype and its relationship to bone mineral density in Hong Kong Chinese. J. Bone Miner. Metab. 23, 261-265. https://doi.org/10.1007/s00774-004-0593-0

Wu, K., Chen, C., Moyzis, R.K., Greenberger, E., Yu, Z., 2016. Gender Interacts with Opioid Receptor Polymorphism A118G and Serotonin Receptor Polymorphism -1438 A/G on Speed-Dating Success. Hum. Nat. Hawthorne N 27, 244-260. https://doi.org/10.1007/s12110-016-9257-8

Youssef, S.S., Abd El Aal, A.M., Nasr, A.S., el Zanaty, T., Seif, S.M., 2013. Interleukin-12B gene polymorphism frequencies in Egyptians and sex-related susceptibility to hepatitis $C$ infection. J. Interferon Cytokine Res. Off. J. Int. Soc. Interferon Cytokine Res. 33, 415419. https://doi.org/10.1089/jir.2012.0161 
medRxiv preprint doi: https://doi.org/10.1101/2020.12.16.20248300; this version posted February 12, 2021. The copyright holder for this preprint (which was not certified by peer review) is the author/funder, who has granted medRxiv a license to display the preprint in It is made available under a CC-BY-NC 4.0 International license.

\section{Supplementary Material}

Both stages of the PubMed literature search employed a Species filter set to Humans only.

\section{Stage 1 Search term:}

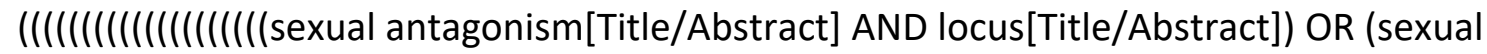
antagonism[Title/Abstract] AND loci[Title/Abstract])) OR (sexual antagonism[Title/Abstract] AND gene[Title/Abstract])) OR (sexual antagonism[Title/Abstract] AND snp[Title/Abstract])) OR (sexual antagonism[Title/Abstract] AND polymorphism[Title/Abstract])) OR (sexual antagonism[Title/Abstract] AND variant[Title/Abstract])) OR (sexual antagonism[Title/Abstract] AND allele[Title/Abstract])) OR (sexually antagonistic[Title/Abstract] AND locus[Title/Abstract])) OR (sexually antagonistic[Title/Abstract] AND loci[Title/Abstract])) OR (sexually antagonistic[Title/Abstract] AND gene[Title/Abstract])) OR (sexually antagonistic[Title/Abstract] AND snp[Title/Abstract])) OR (sexually antagonistic[Title/Abstract] AND polymorphism[Title/Abstract])) OR (sexually antagonistic[Title/Abstract] AND variant[Title/Abstract])) OR (sexually antagonistic[Title/Abstract] AND allele[Title/Abstract])) OR (intralocus sexual conflict[Title/Abstract] AND locus[Title/Abstract])) OR (intralocus sexual conflict[Title/Abstract] AND loci[Title/Abstract])) OR (intralocus sexual conflict[Title/Abstract] AND gene[Title/Abstract])) OR (intralocus sexual conflict[Title/Abstract] AND snp[Title/Abstract])) OR (intralocus sexual conflict[Title/Abstract] AND polymorphism[Title/Abstract])) OR (intralocus sexual conflict[Title/Abstract] AND variant[Title/Abstract])) OR (intralocus sexual conflict[Title/Abstract] AND allele[Title/Abstract])

Stage 2 Search term:

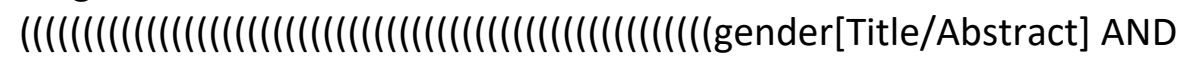
opposite[Title/Abstract] AND locus[Title/Abstract]) OR (gender[Title/Abstract] AND opposite[Title/Abstract] AND loci[Title/Abstract])) OR (gender[Title/Abstract] AND opposite[Title/Abstract] AND gene[Title/Abstract])) OR (gender[Title/Abstract] AND opposite[Title/Abstract] AND snp[Title/Abstract])) OR (gender[Title/Abstract] AND opposite[Title/Abstract] AND polymorphism[Title/Abstract])) OR (gender[Title/Abstract] AND opposite[Title/Abstract] AND variant[Title/Abstract])) OR (sex[Title/Abstract] AND opposite[Title/Abstract] AND locus[Title/Abstract])) OR (sex[Title/Abstract] AND opposite[Title/Abstract] AND loci[Title/Abstract])) OR (sex[Title/Abstract] AND opposite[Title/Abstract] AND gene[Title/Abstract])) OR (sex[Title/Abstract] AND opposite[Title/Abstract] AND snp[Title/Abstract])) OR (sex[Title/Abstract] AND opposite[Title/Abstract] AND polymorphism[Title/Abstract])) OR (sex[Title/Abstract] AND opposite[Title/Abstract] AND variant[Title/Abstract])) OR (sex dependent[Title/Abstract] AND locus[Title/Abstract])) OR (sex dependent[Title/Abstract] AND loci[Title/Abstract])) OR (sex dependent[Title/Abstract] AND gene[Title/Abstract])) OR (sex dependent[Title/Abstract] AND snp[Title/Abstract])) OR (sex dependent[Title/Abstract] AND polymorphism[Title/Abstract])) OR (sex dependent[Title/Abstract] AND variant[Title/Abstract])) OR (sex different[Title/Abstract] AND locus[Title/Abstract])) OR (sex 
medRxiv preprint doi: https://doi.org/10.1101/2020.12.16.20248300; this version posted February 12, 2021. The copyright holder for this preprint (which was not certified by peer review) is the author/funder, who has granted medRxiv a license to display the preprint in It is made available under a CC-BY-NC 4.0 International license.

841

842

843

844

845

846

847

848

849

850

851

852

853

854

855

856

857

858

859

860

861

862

863

864

865

866

867

868

869

870

871

872

873

874

875

876

877

878

879

880

881

882

883

884

885

886
different[Title/Abstract] AND loci[Title/Abstract])) OR (sex different[Title/Abstract] AND gene[Title/Abstract])) OR (sex different[Title/Abstract] AND snp[Title/Abstract])) OR (sex different[Title/Abstract] AND polymorphism[Title/Abstract])) OR (sex different[Title/Abstract] AND variant[Title/Abstract])) OR (gender-dependent[Title/Abstract] AND locus[Title/Abstract])) OR (gender-dependent[Title/Abstract] AND loci[Title/Abstract])) OR (gender-dependent[Title/Abstract] AND gene[Title/Abstract])) OR (genderdependent[Title/Abstract] AND snp[Title/Abstract])) OR (gender-dependent[Title/Abstract] AND polymorphism[Title/Abstract])) OR (gender-dependent[Title/Abstract] AND variant[Title/Abstract])) OR (male[Title/Abstract] AND female[Title/Abstract] AND opposite[Title/Abstract] AND locus[Title/Abstract])) OR (male[Title/Abstract] AND female[Title/Abstract] AND opposite[Title/Abstract] AND loci[Title/Abstract])) OR (male[Title/Abstract] AND female[Title/Abstract] AND opposite[Title/Abstract] AND gene[Title/Abstract])) OR (male[Title/Abstract] AND female[Title/Abstract] AND opposite[Title/Abstract] AND snp[Title/Abstract])) OR (male[Title/Abstract] AND female[Title/Abstract] AND opposite[Title/Abstract] AND polymorphism[Title/Abstract])) OR (male[Title/Abstract] AND female[Title/Abstract] AND opposite[Title/Abstract] AND variant[Title/Abstract])) OR (men[Title/Abstract] AND women[Title/Abstract] AND opposite[Title/Abstract] AND locus[Title/Abstract])) OR (men[Title/Abstract] AND women[Title/Abstract] AND opposite[Title/Abstract] AND loci[Title/Abstract])) OR (men[Title/Abstract] AND women[Title/Abstract] AND opposite[Title/Abstract] AND gene[Title/Abstract])) OR (men[Title/Abstract] AND women[Title/Abstract] AND opposite[Title/Abstract] AND snp[Title/Abstract])) OR (men[Title/Abstract] AND women[Title/Abstract] AND opposite[Title/Abstract] AND polymorphism[Title/Abstract])) OR (men[Title/Abstract] AND women[Title/Abstract] AND opposite[Title/Abstract] AND variant[Title/Abstract])) OR (boys[Title/Abstract] AND girls[Title/Abstract] AND opposite[Title/Abstract] AND locus[Title/Abstract])) OR (boys[Title/Abstract] AND girls[Title/Abstract] AND opposite[Title/Abstract] AND loci[Title/Abstract])) OR (boys[Title/Abstract] AND girls[Title/Abstract] AND opposite[Title/Abstract] AND gene[Title/Abstract])) OR (boys[Title/Abstract] AND girls[Title/Abstract] AND opposite[Title/Abstract] AND snp[Title/Abstract])) OR (boys[Title/Abstract] AND girls[Title/Abstract] AND opposite[Title/Abstract] AND polymorphism[Title/Abstract])) OR (boys[Title/Abstract] AND girls[Title/Abstract] AND opposite[Title/Abstract] AND variant[Title/Abstract])) OR (gender[Title/Abstract] AND opposite[Title/Abstract] AND allele[Title/Abstract])) OR (sex[Title/Abstract] AND opposite[Title/Abstract] AND allele[Title/Abstract])) OR (sex dependent[Title/Abstract] AND allele[Title/Abstract])) OR (sex different[Title/Abstract] AND allele[Title/Abstract])) OR (genderdependent[Title/Abstract] AND allele[Title/Abstract])) OR (male[Title/Abstract] AND female[Title/Abstract] AND opposite[Title/Abstract] AND allele[Title/Abstract])) OR (men[Title/Abstract] AND women[Title/Abstract] AND opposite[Title/Abstract] AND allele[Title/Abstract])) OR (boys[Title/Abstract] AND girls[Title/Abstract] AND opposite[Title/Abstract] AND allele[Title/Abstract]) 
medRxiv preprint doi: https://doi.org/10.1101/2020.12.16.20248300; this version posted February 12, 2021. The copyright holder for this preprint (which was not certified by peer review) is the author/funder, who has granted medRxiv a license to display the preprint in perpetuity.

It is made available under a CC-BY-NC 4.0 International license .

887

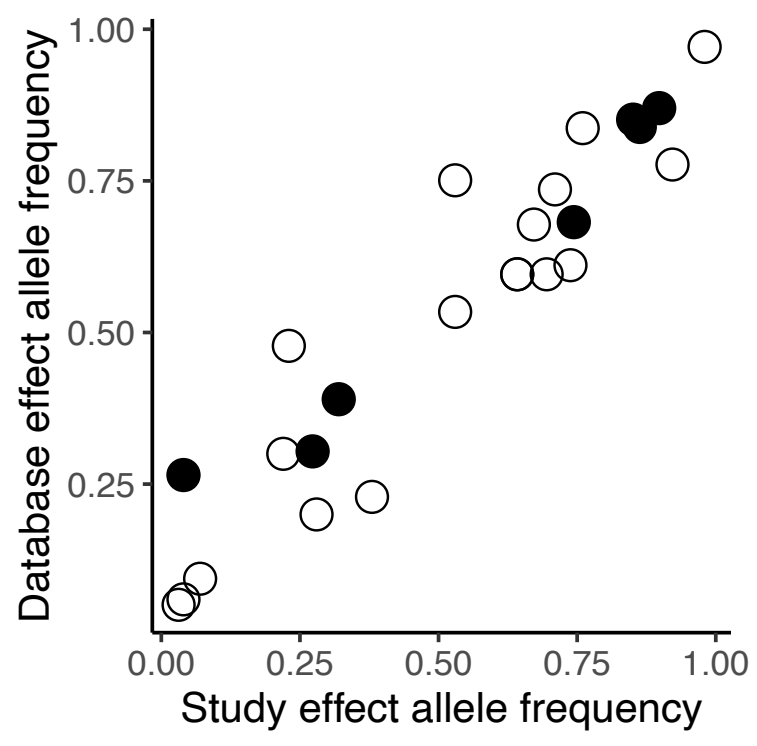
frequencies for the same alleles obtained from the 1000 genomes database (0.94). Filled circles represent disease risk/severity related variants while open circles represent complex trait variants. 
medRxiv preprint doi: https://doi.org/10.1101/2020.12.16.20248300; this version posted February 12, 2021. The copyright holder for this preprint (which was not certified by peer review) is the author/funder, who has granted medRxiv a license to display the preprint in It is made available under a CC-BY-NC 4.0 International license .

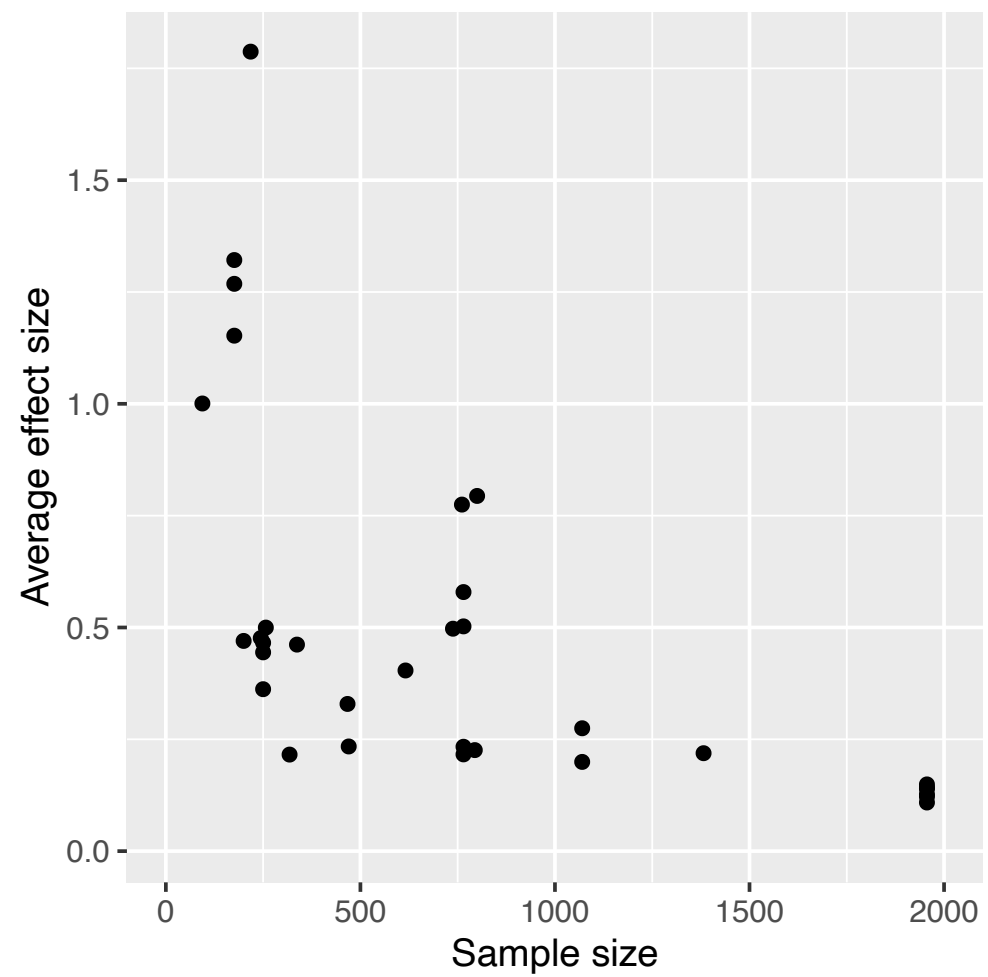

Figure S2. Relationship between study sample size and average extracted effect size across all studies. 
medRxiv preprint doi: https://doi.org/10.1101/2020.12.16.20248300; this version posted February 12, 2021. The copyright holder for this preprint (which was not certified by peer review) is the author/funder, who has granted medRxiv a license to display the preprint in It is made available under a CC-BY-NC 4.0 International license .

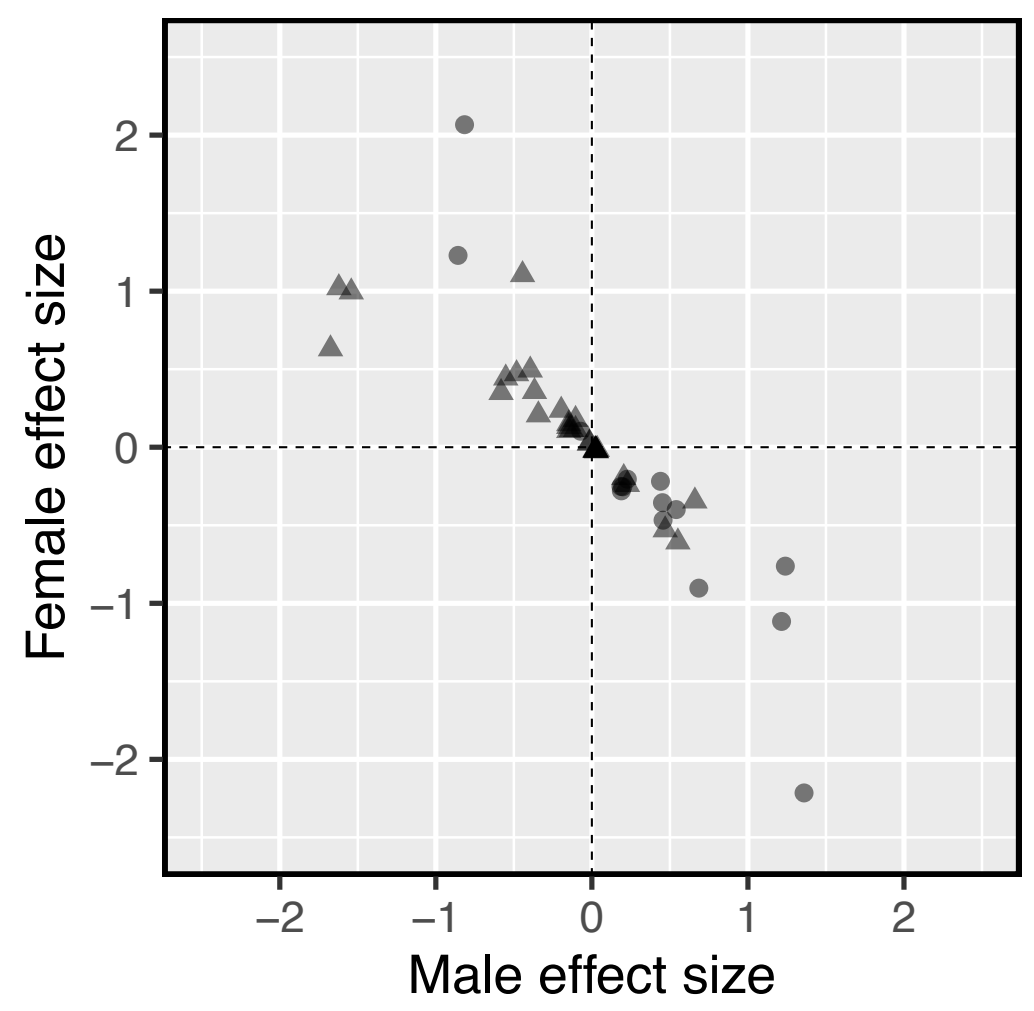

901

Figure S3. Female effect size and male effect size are negatively correlated in SA alleles. represent sex-opposite complex trait variants, circular points represent disease risk/severity variants. 
medRxiv preprint doi: https://doi.org/10.1101/2020.12.16.20248300; this version posted February 12, 2021. The copyright holder for this preprint (which was not certified by peer review) is the author/funder, who has granted medRxiv a license to display the preprint in perpetuity.

It is made available under a CC-BY-NC 4.0 International license .

907
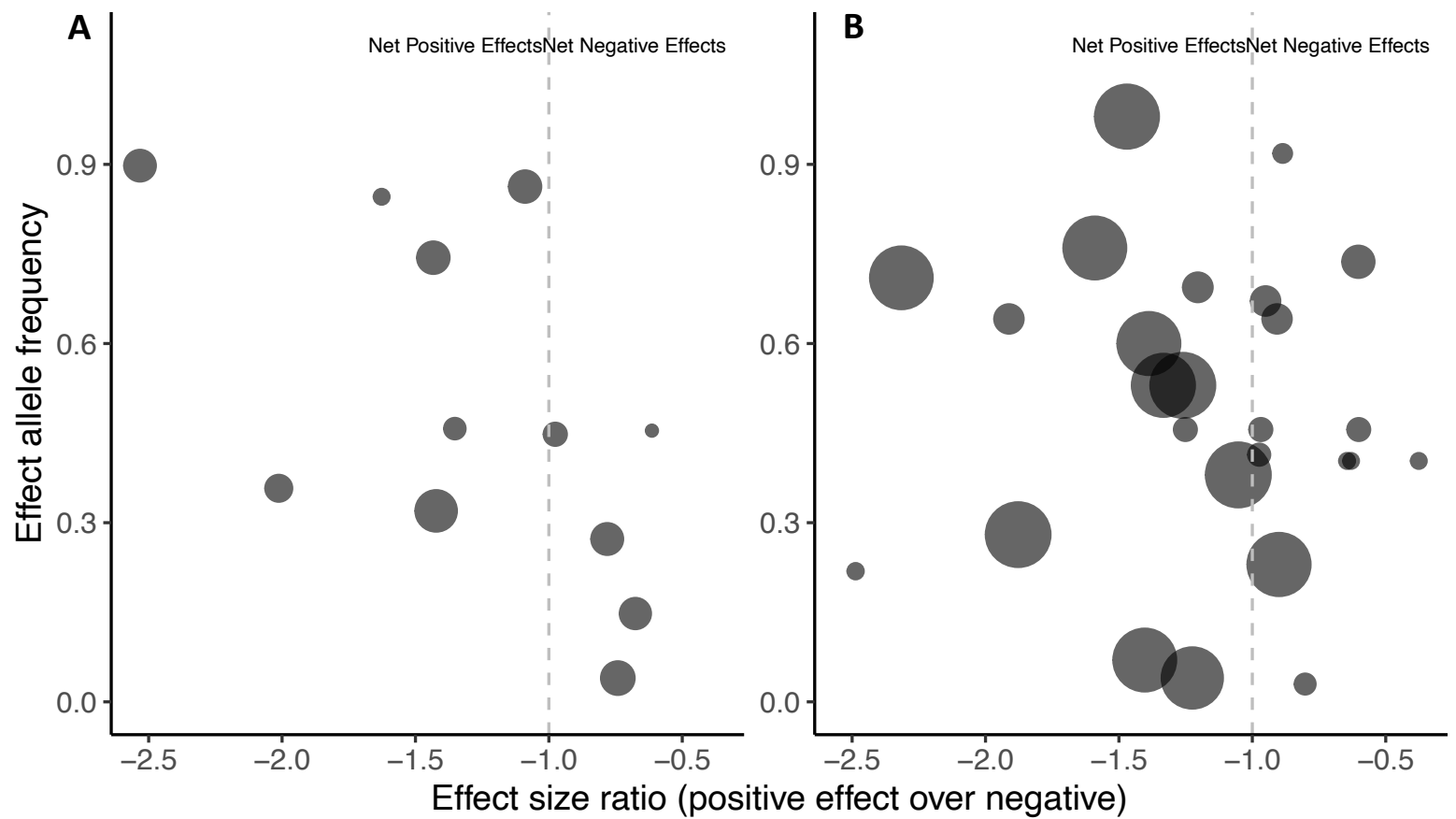

Effect size ratio (positive effect over negative)

910 Figure S4. The relationship between effect allele frequency and effect size ratio, grouped

911 by trait class. Points to the right of the vertical dotted line have a greater negative effect than

912 positive. A. Disease risk/severity variants. B. Complex traits. Point size is based on the variance

913 of the effect size ratio, with smaller variance having larger point sizes and greater weighting 914 in the statistical model. 